\title{
Ecological, Typological Properties and Photosynthetic Activity (FAPAR) of Common Beech (Fagus sylvatica L.) Ecosystems in Croatia
}

\author{
Ivan Pilaš ${ }^{1 *}$, Ivan Medved ${ }^{1}$, Jasna Medak ${ }^{1}$, Melita Perčec Tadić ${ }^{2}$, Damir Medak $^{3}$
}

(1) Croatian Forest Research Institute, Division of Ecology, Cvjetno naselje 41, HR-10450 Jastrebarsko, Croatia; (2) Meteorological and Hydrological Service, Grič 3, HR-10000 Zagreb, Croatia; (3) University of Zagreb, Faculty of Geodesy, Kačićeva 26, HR-10000 Zagreb, Croatia

* Correspondence: e-mail: ivanp@sumins.hr
Citation: PILAŠ I, MEDVED I, MEDAK J, PERČECTADIĆ M, MEDAK D 2016 Ecological, Typological Properties and Photosynthetic Activity (FAPAR) of Common Beech (Fagus sylvatica L.) Ecosystems in Croatia. Southeast Eur for 7 (2): 73-89. DOI: https://doi. org/10.15177/seefor.16-13

Received: 1 Aug 2016; Revised: 24 Sep 2016; Accepted: 26 Sep 2016; Published online: 20 Oct 2016; 9 Mar 2017

\begin{abstract}
Background and purpose: The purpose of this study was to assess the structural and functional properties of common beech forest ecosystems in Croatia across a wide macro-climatic gradient (Mediterranean, Alpine and Continental) and to gain insight into the ways they adapt to progressing short-term climatic extremes and anomalies.

Material and Methods: Research was undertaken by integration of the expert based, country scale typological delineation of 13 beech ecosystem types, climatic and topographic grids and indices of ecosystem performances such as the JRC FAPAR (Fraction of Absorbed Photosynthetically Active Radiation).

Results: This study reveals preferential environmental conditions for beech ecosystem types together with limiting conditions in three margins of the beech distribution area: highest altitudinal zone, south-eastern continental Pannonian zone and the Mediterranean. The results show that the common beech can adapt to a very wide range of environmental conditions: annual mean temperatures from $2.1^{\circ} \mathrm{C}$ to $13.5^{\circ} \mathrm{C}$, annual precipitation from $739 \mathrm{~mm}$ to $3444 \mathrm{~mm}$, and altitudinal range from $20.3 \mathrm{~m}$ up to $1576 \mathrm{~m}$ above sea level. FAPAR reveals some new insight into the adaptive potential and response mechanisms of the common beech to emerging climate change.

Conclusion: The common beech has great potential to adapt to increasing spring warming by a preterm shift of phenology onset and retain relatively stable productivity during the phenology peak in July and August, unrelated to external climatic forcing. These findings indicate that the flexibility of phenological timing, especially during springtime, present one of the important mechanisms of adaptation and resilience of the common beech.
\end{abstract}

Keywords: Common beech (Fagus sylvatica L.), JRC FAPAR, environmental limits, adaptation, resilience, climate change

\section{INTRODUCTION}

The common or European beech (Fagus sylvatica L.) is one of the major forest trees in the mountain regions of Europe with an approximated coverage of slightly more than $217,000 \mathrm{~km}^{2}$, which is less than one third of the potential beech forest cover of approximately $907,000 \mathrm{~km}^{2}$ according to Bohn et al. [1]. It has an extremely broad climatic and edaphic amplitude, ranging from the southern regions of the Baltic States to Sicily and from Southern England, Brittany in France, and the Cantabrians in Spain to the lowlands in north eastern Poland, east of the
Carpathians in Moldavia EEA 2007 [2]. Penetration of the beech above the current range of distribution is limited mainly by climatic conditions. A growing season that is too short, low winter temperatures and late frost in spring limits beech distribution at its northern and eastern boundaries and high altitudes [3]. On the other hand, water deficiency limits beech spread to the southern Europe and Mediterranean. The beech gradually expanded in response to the local climate, atmosphere and soils since the last glaciers receded over 10,000 years ago. However, 
climate change and intensification of extreme climatic conditions (droughts) are predicted to lead to a drastic reduction in suitable sites for the beech. Regarding the stands in their current zonal position, $56-96 \%$ of present day beech forests might be outside their present bioclimatic niche by 2050 [4] mainly in the South of France, Italy and the Balkan Peninsula [5]. Climatic factors limit the progression of the beech in the south-eastern range, most directly expressed throughout Ellenberg's climate quotient [4, 6, 7]. However, future predictions of beech distribution, solely based on long-term averages are prone to uncertainty because of the influence of advanced climatic extremes and intrinsic adaptive capacity of beech. At the xeric edge, subsistence of the beech is more influenced by short-term dry periods than the long-term climatic means $[8,9]$. Adaptation to the local environment may lead to genetic and phenotypic structured populations in a few generations, depending on the forest management system applied [5]. Therefore, the adaptive capacity of the beech should not be ignored in the assessment of future distribution. The adaptation strategy of forest trees is receiving growing attention given expected climatic changes. The scarcity of reliable information regarding responses to macroclimatic changes is a central problem and obstacle in planning for the future [6]. To formulate realistic predictions, both the nature of adaptation to past and current climate, and the level of sensitivity to sudden environmental changes have to be understood and properly interpreted.

Due to its very broad environmental niche, the beech constitutes a variety of vegetation types across Europe. This is particularly common in the southern limits of its distribution range, on the Balkan Peninsula, where beech forests are characterized by the high diversity of floral components. This is due to the fact that during the last ice age, the area in the south-eastern periphery of the Alps i.e. the Balkan Peninsula, presented microrefugia that are considered as the main source areas for the subsequent colonization of central and northern Europe by the beech [10]. Nowadays, beech forests in this area contain the variety of "Iliric" floral elements that cannot be found in other parts of Europe, which withstood the last glacial period. Recently, with the goal of placing the EU beech forest on the list of world heritage property, a comprehensive regionalization and formation of Beech Forest Regions was brought about [11]. In the framework of this activity, 12 European Beech Forest Regions were defined, and one of them includes the Illyric Beech Forest Region that covers Slovenia, Croatia and Bosnia-Herzegovina. Another recent comprehensive effort on an EU scale presents the classification of European forest types, Categories and types for sustainable forest management reporting and policy (EEA [2]). EEA classification defines two European beech forest types in the Illyric Beech Forest Region. The Illyrian sub-mountainous beech forest prevails in the Dinarides and mid-Pannonic hills, while in the higher altitudinal range of distribution, beech forests with silver fir and common spruce, forming Illyrian mountainous beech forest type prevail. However, on a local country scale in Croatia, the long-term forest ecosystem studies based on a typological approach [12] have been undertaken. The goal of these studies was in identifying, assessing and mapping the specific forest ecological-managerial types (ecosystems) based on common soil-vegetation properties. The purpose of this classification was to define the optimal productivity (yield tables) of forest stands with respect to site potential and to propose the most suitable means of forest management and regeneration that can preserve ecosystem sustainability in the long-term. As a result of these research activities, a total of 13 beech forest types (ecosystems) were identified and delineated across the country. Beech forests were also categorized in four broader bioclimatic groups with respect to climate-vegetation relationship.

A broad temperature and precipitation gradient over the narrow geographical range in Croatia $\left(3-17^{\circ} \mathrm{C}\right.$ of yearly average temperatures and $300-3500 \mathrm{~mm}$ of total yearly rainfall) contribute to the variety of macroclimatic conditions. Croatia also intersects four of the main European biogeographical regions on a relatively short spatial extent (Continental, Pannonian, Alpine and Mediterranean). Therefore, delimited beech forest types cover an extensive environmental range; from optimal conditions enabling the highest productivity, to limiting conditions that prevail on the margins of their distribution area. Along the Adriatic littoral region, there is a very sharp transition from the warm and dry Mediterranean climate not suitable for the beech. Beech populations in this boundary region are in environmental limits, partly adapted to the Mediterranean climate. The other xeric limit is on the lowest slopes of the eastern parts of Pannonian hills, in the transition towards the semi-arid SouthEastern climatic zone. The third boundary for the beech is in the highest hilltops of the Dinaric Alps, in the upper altitudinal limits of forest vegetation. This extensive environmental setting across a narrow area is very suitable for assessment of the beech climatic niche width, together with its responses to various climatic anomalies and extreme events that can provide new insights into beech adaptation potential. The regional scale assessment in the transitional area of South-eastern Europe and the Mediterranean could provide important clues as to how beech forest types are coping with a warmer environment and how they are adapting to extreme climatic conditions, such as dry spells.

Consequently, the main objectives of this study were to assess the structural and functional properties of beech forest ecosystems in Croatia across a wide climatic gradient (Mediterranean, Alpine and Continental) and to gain some clues about the means of adaptation to spatio - temporal climatic extremes and anomalies. This was undertaken by: (1) assessing the main ecological properties in terms of the yearly mean temperature, annual precipitation and the Ellenberg climate quotient of 13 previously delimited ecosystem types; (2) assessing the main typological properties such as topography (altitude, slope and aspect) and interactions with edaphic factors; (3) assessing the vegetation activity of beech forests using the proxy remote sensing indices such as FAPAR (Fraction of Absorbed Photosynthetically Active Radiation); and (4) provide an assessment of responses and resilience of the beech forests to climatic anomalies, based on FAPAR datasets for the period of observation (1998-2005).

\section{MATERIALS AND METHODS}

\section{Study Area}

Croatia is situated in Central and Southeast Europe between latitudes $42^{\circ}$ and $47^{\circ}$ and longitudes $13^{\circ}$ and $20^{\circ}$. The Pannonian Basin, Dinaric Alps and Adriatic Basin constitute the major geomorphographic areas (Figure 1). The major mountain ranges are the Dinaric Alps following the littoral Adriatic zone, ranging from sea level up to $1831 \mathrm{~m}$ and the Pannonian hills (Ivančica, Medvednica, Bilogora, Psunj, Papuk, Dilj) in the continental area, ranging up to $1060 \mathrm{~m}$. Parent material in the carstic region of the Dinaric Alps constitute Mesozoic limestones and dolomites with protrusions of silicate and silicate-carbonate clastites and only locally magmatites [13]. Unlike the Dinaric area, the soils 

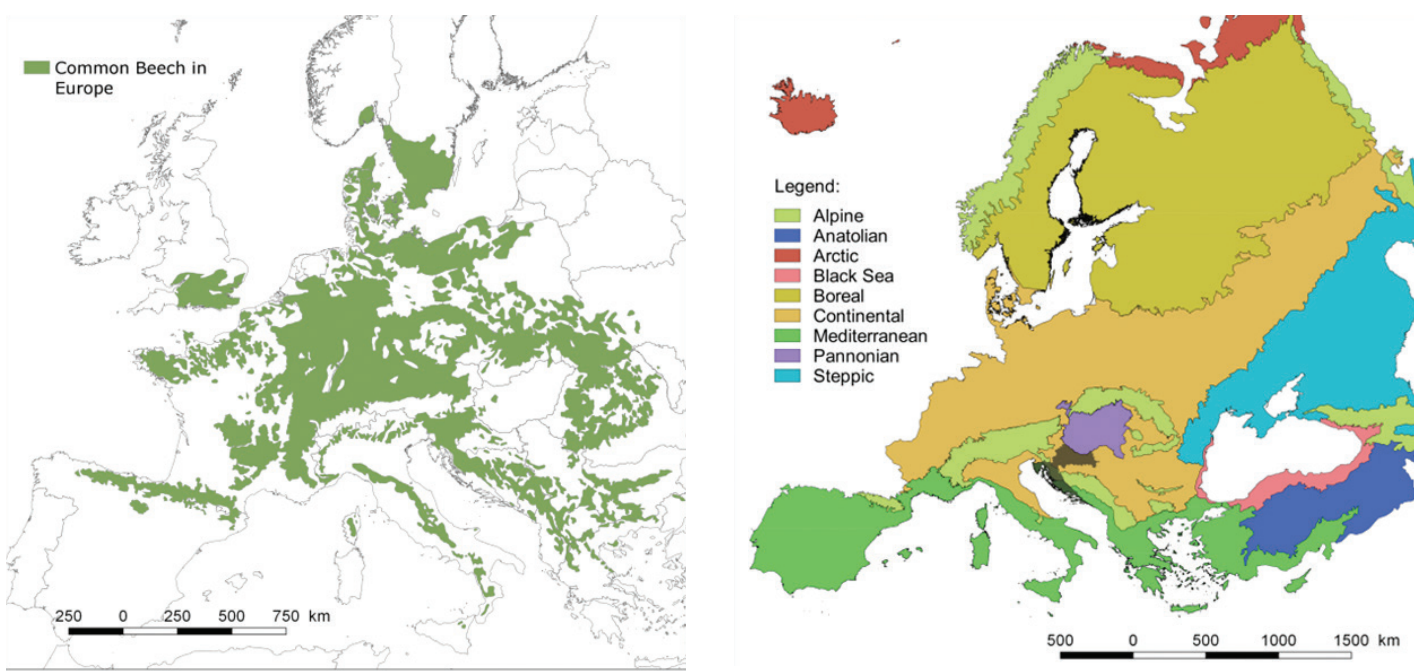

FIGURE 1. Distribution of common beech in Europe (left); European biogeographic regions with Croatia country position (right)

of the beech forests of the Pannonian hills are characterised by predominantly physically easily weathered substrates. They are mainly various unconsolidated clastites, marls, sandstones and metamorphic rocks. Croatia has per-humid, humid and subhumid climates according to the Thornthwaite climate classification [14]. A humid climate is prevalent in a large part of the continental lowlands, a subhumid climate only in the eastern part and a perhumid climate in the highlands [15]. In coastal Croatia, there are per-humid, humid and subhumid climates. In the past 50 years, a significant increase in the mean annual temperature values (from $0.2^{\circ} \mathrm{C}$ to $0.4^{\circ} \mathrm{C}$ per decade) is found in Croatia's mountainous region. The overall (annual) positive trend is mainly due to significant positive summer and spring trends (from $0.3^{\circ} \mathrm{C}$ to $0.5^{\circ} \mathrm{C}$ per decade). In terms of precipitation, the prevailing trends in the mountains are negative (from $-17 \mathrm{~mm}$ to $-11 \mathrm{~mm}$ per decade) except at the highest-altitude stations where the dominant trend is positive (32 $\mathrm{mm}$ per decade). An analysis of precipitation [16], based on a dense network of rain-gauge stations in Croatia, reveals a significant decrease in the total annual precipitation amounts of $-50.6 \mathrm{~mm}$ per decade in the mountainous regions. A significant summer decrease mainly governs the annual trend, and, in the northern part, also partly a spring decrease. Based on available literature, it can be concluded that warming of the climate in the Croatian Highlands is currently occurring, which is especially evident during the warm half-year (spring and summer). This warming is accompanied by drying trends, thus indicating that the mountainous regions in Croatia are prone to significant climate change.

\section{Geospatial Data of Forest Types, Climate and Topography}

The definition of 13 beech forest types (ecosystems) used in this research was based on the comprehensive forest ecosystem inventory i.e. typological surveys that were mostly performed between 1970 and 1990 at the Croatian Forest Research Institute. Typological or ecosystem-based assessments were comprised of detail, a plot scale field survey of soil properties including geological and climate characteristics, floristic composition, and stand structural properties in numerous locations. Comprehensive insights into the results of the aforementioned long-term activities, concerning determined soil and vegetation characteristics that constitute beech ecosystems in Croatia, can be found in the publications of Pernar and Bakšić [13] and Vukelić and Baričević [17]. Geospatial coverage with delineated forest types was produced throughout 2003-2007 in the framework of the project: "Development of the Dynamical geo-information system of forest ecosystems in Croatia". Delineation of forest cover was provided from aerial orthophoto images and available remote sensing data. Further ecosystem stratification was undertaken through expert knowledge and previously gathered information, forest inventory data, draft survey maps, study reports and publications. The resulted map of beech ecosystem types is shown in Figure 2 and Table 1.

Topographic parameters (mean, minimum, maximum of altitude, slope and aspect) were derived from the digital terrain model (DTM) available in $25 \mathrm{~m}$ grid resolution (Figure 3 ), based on topographic maps of Croatia 1:5000 and 1:25 000. For the purpose of this study, the DTM was scaled on a $1000 \mathrm{~m}$ grid resolution. The spatial grid of mean annual air temperature (Figure 3) was based on measurements from 152 main and climatological stations in Croatia during the period 1961-1990. The grid of the mean annual precipitation (Figure 3 ) for the similar period was based on measurements of the mean daily precipitation from 567 main, climatological and rain gauging stations. The resolution of temperature and precipitation grids was also $1000 \mathrm{~m}$. In addition, Ellenberg's climate quotient (EQ) [18] was calculated from grids of the mean temperature of the warmest month (July, $\mathrm{T}_{07}$ ) divided by annual precipitation $(\mathrm{Pa})$ :

$$
E Q=1000\left(T_{07} / P a\right)
$$

\section{Estimation of the FAPAR Values and Resilience Metrics}

Freely available, monthly FAPAR (Fraction of Absorbed Photosinthetically Active Radiation) data [19] was obtained from the JRC FAPAR website (http://fapar.jrc.ec.europa.eu). Data was acquired in monthly intervals for the period from 1998 to 2005. Basic manipulation and transformation of the data in a 
suitable format for SAGA GIS spatial analysis was performed by BEAM VISAT software. Monthly FAPAR images, 96 in total from 1998-2005, were then clipped with the 13 area shape files that represent envelopes of beech ecosystems. Associated FAPAR pixels (with a $1 \mathrm{~km}$ spatial resolution) were extracted (Figure 5). However, so as to eliminate the problem of the false high FAPAR intensity (the appearance of extreme FAPAR values during the winter season, very possibly as a reflection of snow cover), only months in seasons with certain vegetation activity (from March to November) were used for analysis. Average monthly FAPAR values for each of the 13 area samples, from March to November within the eight year period, were calculated from related pixels using "Spatial and geostatistic analysis module" in SAGA GIS. Further data processing, statistics and graphical representation were performed in $\mathrm{R}$ software for statistical computing.

In order to quantify ecosystem responses indices of resilience were applied that represent the concepts of resistance, recovery, resilience and relative resilience following the procedure of Lloret et al. [20], Sánchez-Salguero et al. [21], Herrero and Zamora [22] and Pilas et al. [23]. In general, resistance is the inverse of performance reduction during extreme drought and presents the ratio between performance during and before drought. Recovery is the ability to recover relative to the performance reduction undergone during drought and presents the ratio between performance after and during extreme drought. Resilience is the capacity to return to pre-drought performance levels and presents the ratio between the performance before and after drought. Relative resilience is the resilience weighted by the performance reduction during drought. In this study an adapted approach was applied, previously developed by Pilas et al. [23] for FAPAR monthly time series. The relationship between midseason FAPAR in July $\left(F_{m s}\right)$ was studied, which is very close to the maximum extent of photosynthetic activity for the season, as well as pre and post mid season vegetation performances. The effect of variations of FAPAR during intensive vegetation growth in the April-June period $\left(\mathrm{F}_{\text {pre }}\right)$ on the mid-season FAPAR performance were analyzed, i.e. resistance (rt7) of $F_{m s^{\prime}}$ and the effect of midseason FAPAR on the vegetation activity during the later stage and the senescence period in August-October, $\left(\mathrm{F}_{\text {post }}\right)$ i.e. recovery (rc7). As a follow up to these calculations we estimated the differences in resilience ( $r 57$ ) and relative resilience of ecosystems (rr7) based on intra-annual variations of photosynthetic activity. We calculated these indices using the following formulae:

$$
\begin{aligned}
& \mathrm{rt} 7=F_{\mathrm{ms}} /\left(\left(F_{\mathrm{ms}-1}+F_{\mathrm{ms}-2}+F_{\mathrm{ms}-3}\right) / 3\right)=F_{\mathrm{ms}} / F_{\text {pre }} \\
& \mathrm{rc} 7=\left(\left(F_{\mathrm{ms}+1}+F_{\mathrm{ms}+2}+F_{\mathrm{ms}+3}\right) / 3\right) / F_{\mathrm{ms}}=F_{\text {post }} / F_{\mathrm{ms}} \\
& \mathrm{rs} 7=\left(F_{\mathrm{ms}+1}+F_{\mathrm{ms}+2}+F_{\mathrm{ms}+3}\right) /\left(F_{\mathrm{ms}-1}+F_{\mathrm{ms}-2}+F_{\mathrm{ms}-3}\right)^{2}=F_{\text {post }} / F_{\text {pre }} \\
& \mathrm{rr} 7=F_{\text {post }} \times F_{\mathrm{ms}} / F_{\text {pre }}
\end{aligned}
$$

where $F_{\text {ms }}, F_{\text {ms-t }}, F_{\text {mstt }}$ are FAPAR values for the mid-season (July),

\begin{tabular}{|c|c|c|c|}
\hline Bioclimate & $\begin{array}{l}\text { Forest } \\
\text { ecosystem }\end{array}$ & Phytocenoses & Dominant soil type (WRB classification) \\
\hline B & 1 & $\begin{array}{l}\text { (Illyrian) Subalpine beech forest } \\
\text { (Ranunculo platanifolii-Fagetum /Ht. 1938/Marinček et al. 1993) }\end{array}$ & leptic CAMBISOL rhodic \\
\hline \multirow[t]{3}{*}{ C } & 1 & $\begin{array}{l}\text { Dinaric beech-fir forest } \\
\text { Omphalodo-Fagetum (Treg. 1957) Marinček et al. } 1993\end{array}$ & folic CAMBISOL, eutric \\
\hline & 3 & $\begin{array}{c}\text { Dinaric beech-fir forest } \\
\text { Omphalodo-Fagetum (Treg. 1957) Marinček et al. } 1993\end{array}$ & lithic, mollic LEPTOSOL, humic \\
\hline & 4 & $\begin{array}{l}\text { Pannonian beech-fir forest } \\
\text { Festuco drymeiae-Abietetum Vukelić et Baričević 2007) }\end{array}$ & haplic CAMBISOL, dystric, endoskeletic \\
\hline \multirow[t]{7}{*}{ D } & 1 & $\begin{array}{l}\text { (Illyric) montane beech forest } \\
\text { (Lamio orvale-Fagetum sylvaticae } \mathrm{Ht} \text {. 1938) }\end{array}$ & folic CAMBISOL, eutric \\
\hline & 2 & $\begin{array}{l}\text { (Illyric) montane beech forest } \\
\text { (Lamio orvale-Fagetum sylvaticae Ht. 1938) }\end{array}$ & $\begin{array}{l}\text { hypersceletic, rendzic LEPTOSOL, brunic, } \\
\text { skeletic }\end{array}$ \\
\hline & 3 & $\begin{array}{l}\text { (Illyric) montane beech forest } \\
\text { (Lamio orvale-Fagetum sylvaticae Ht. 1938) }\end{array}$ & LEPTOSOL, rendzic, mollic \\
\hline & 4 & $\begin{array}{l}\text { (Illyric) montane beech forest } \\
\text { (Lamio orvale-Fagetum sylvaticae } \mathrm{Ht} \text {. 1938) }\end{array}$ & gleyic, cutanic LUVISOL, clayic, epidystric \\
\hline & 5 & $\begin{array}{l}\text { (Illyric) montane beech forest } \\
\text { (Lamio orvale-Fagetum sylvaticae } \mathrm{Ht} \text {. 1938) }\end{array}$ & cutanic LUVISOL, arenic, siltic \\
\hline & 6 & $\begin{array}{l}\text { (Illyric) montane beech forest } \\
\text { (Lamio orvale-Fagetum sylvaticae } \mathrm{Ht} \text {. 1938) }\end{array}$ & folic CAMBISOL, dystric, endoskeletic \\
\hline & 7 & $\begin{array}{l}\text { Submontane Pannonian beech forests } \\
\text { (Cephalathero longifoliae-Fagetum Vukelić, Baričević et Šapić } \\
\text { 2012) }\end{array}$ & gleyic, cutanic LUVISOL, clayic, epidystric \\
\hline \multirow[t]{2}{*}{$\mathrm{H}$} & 1 & $\begin{array}{l}\text { Sub-mediterranean beech forest } \\
\text { (Seslerio-Fagetum sy/vaticae/Ht. 1950/M. Wraber 1960) }\end{array}$ & leptic CAMBISOL rhodic (Calcocambisol) \\
\hline & 2 & $\begin{array}{l}\text { Termophyilic continental beech forest } \\
\text { (Ostryo-Fagetum sylvaticae Wraber ex Trinajstić 1972) }\end{array}$ & LEPTOSOL, rendzic, mollic \\
\hline
\end{tabular}
the previous t months and t months after, respectively, rt7, rc7, rs7, rr7 (mid-seasonal resilience indices).

TABLE 1. The dominant soil and vegetation pairs constituting the common beech ecosystems 


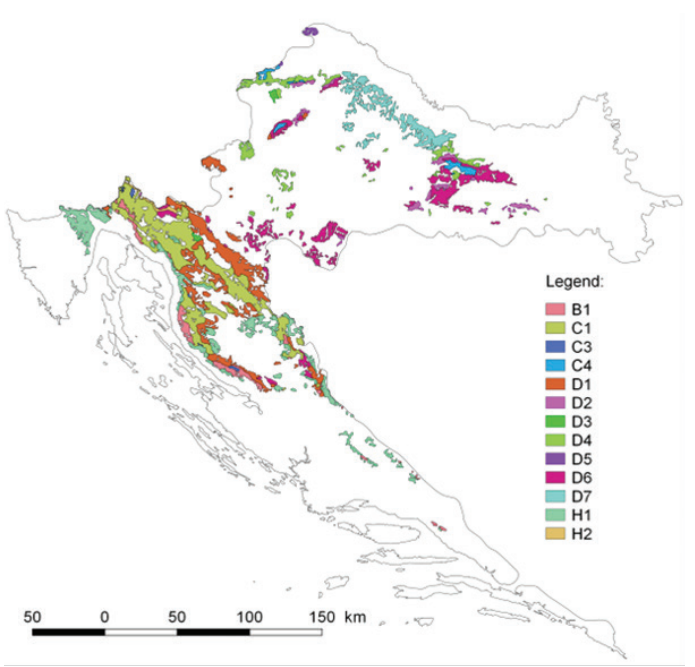

FIGURE 2. Distribution of 13 common beech ecosystems in Croatia

\section{RESULTS}

\section{Main Topographic and Climatic Properties}

Table 1 shows a summary statistics of the main topographic and climatic grids concerning 13 beech ecosystem types. The results indicate the proportion of area of each individual forest type. The most abundant is ecosystem $\mathrm{C} 1$ with an approximate area of $2825 \mathrm{~km}^{2}$ and the smallest ecosystem is C3 with $41 \mathrm{~km}^{2}$. The obtained results show that the beech appears across a very broad range of environmental conditions, from locations very close to sea level $(20.3 \mathrm{~m})$ to the highest altitudinal belts of the Dinaric Alps (1576 m). The average values of the assessed parameters indicate the preferential conditions of a particular ecosystem regarding general macroclimatic properties. However, minimal and maximal values are more influenced by microclimate and specific topographic settings. This is clearly visible in the Sub-Mediterranean beech forest $(\mathrm{H} 1)$ which, in general, appears at higher average altitudes ( $886 \mathrm{~m}$ ) of the coastal zone, but in specific microclimatic conditions such as in north-western slopes of Učka Mountain in the Istrian Peninsula, can reach the lowest elevations of $20.3 \mathrm{~m}$, the boundaries of carstic field Čepić Field in the hinterland. Elevation is noticeable (Figure 6), a very strong differentiating factor of three bioclimatic groups $(B, C, D)$ which are based on relatively uniform vegetation strata. For example, at altitudes of $559 \mathrm{~m}$ in the Pannonian and 936-1031 $\mathrm{m}$ in the Dinaric region, there is a prevalence of beech - fir mixed forests, while pure beech forests occupy the zones below and above this range. At the inner bioclimatic scale, edaphic factors are more relevant in the differentiation of ecosystem types. Slope also shows a gradual increase across the ecosystem altitudinal range - ecosystems in the lower altitudes (bioclimate D) occupy milder slopes than ecosystems in the higher zones (bioclimates $\mathrm{B}$ and $\mathrm{C}$ ). Aspect is quite invariant across the ecosystem range except for ecosystem H2 (Thermophilic continental beech forest), which presents a specific exception appearing dominantly on the eastern slopes. However, the prevailing "thermophilic" vegetation properties of $\mathrm{H} 2$ could also be explained by the character of the
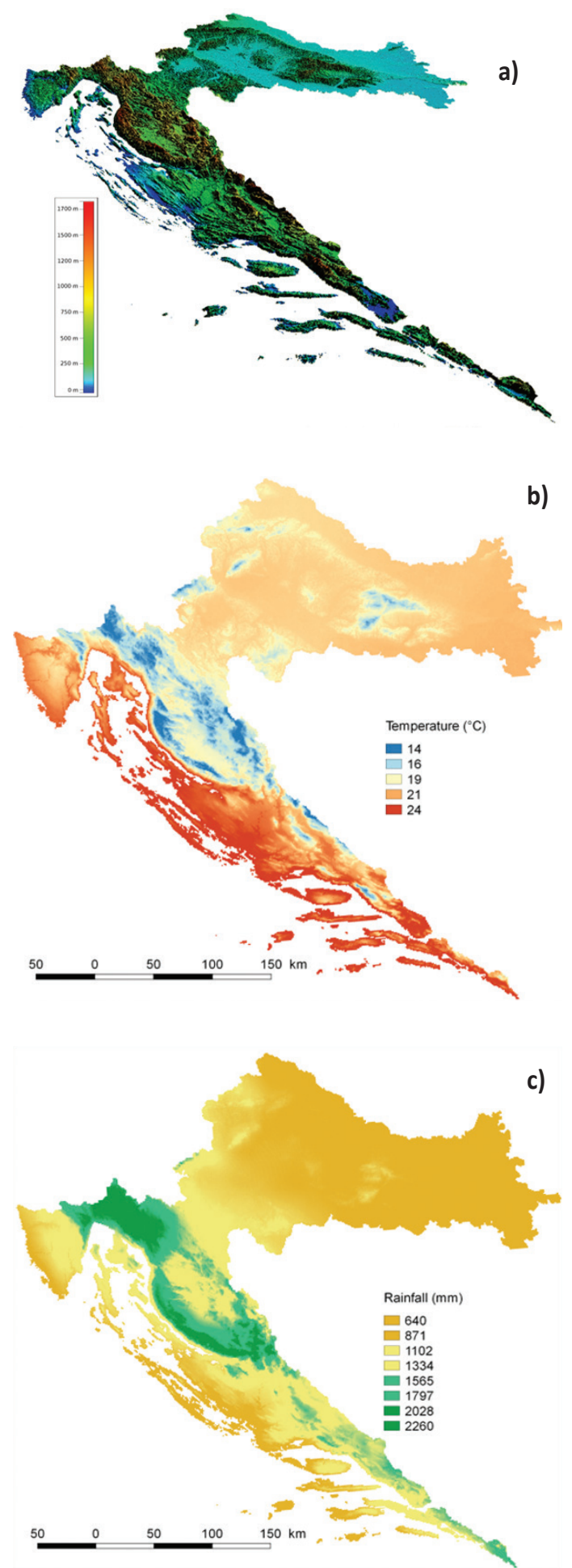

FIGURE 3. Digital elevation model (a), average temperature, based on 1961-1990 average (b), total rainfall, based on 1961-1990 average (c) 

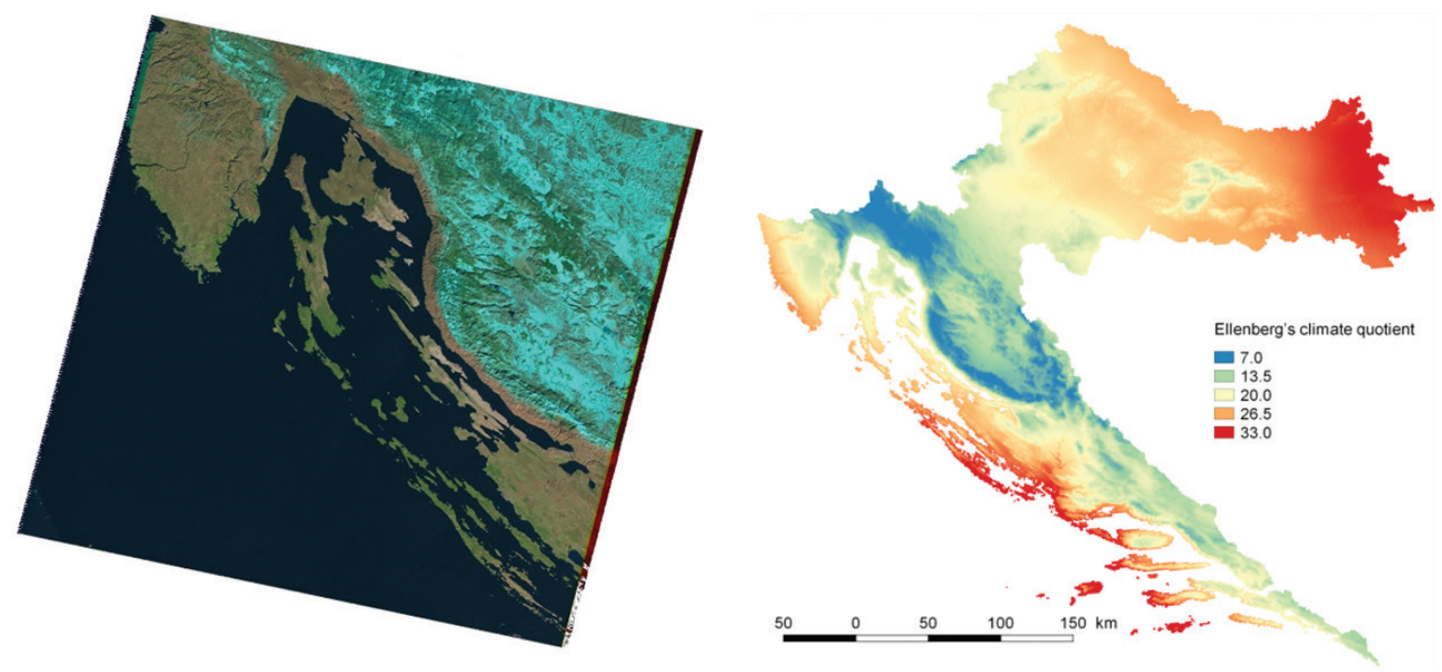

FIGURE 4. Snow boundary indicating the limits of the common beech distribution in Mediterranean (left), spatial coverage of Ellenberg's climate quotient (right)
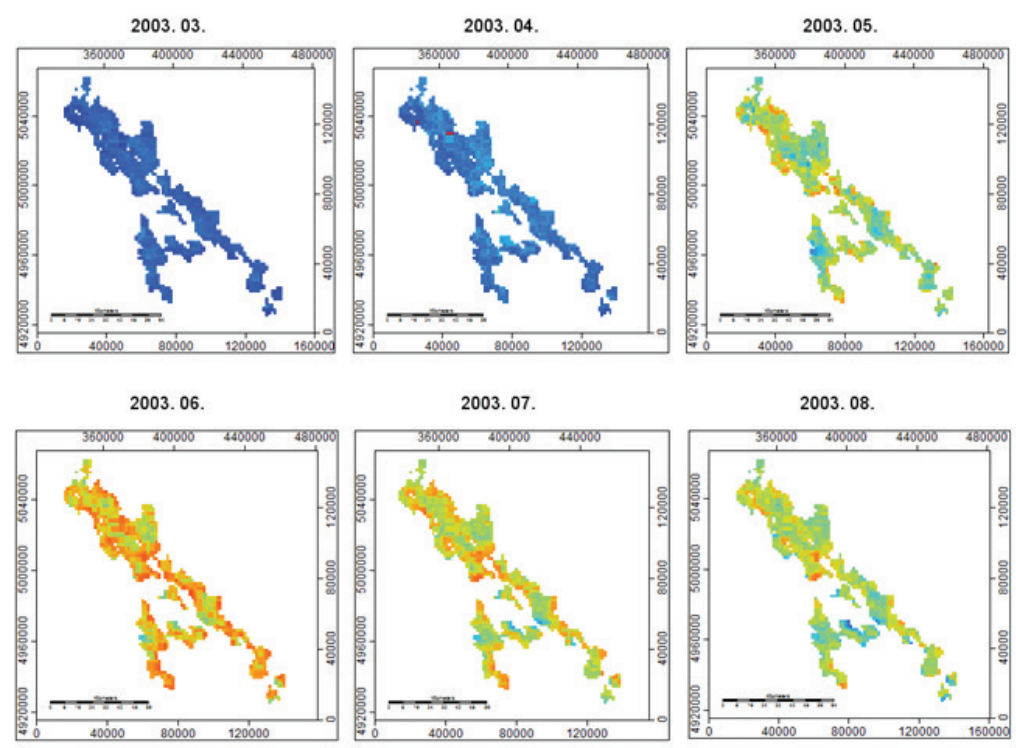

2003. 09.

2003. 10.
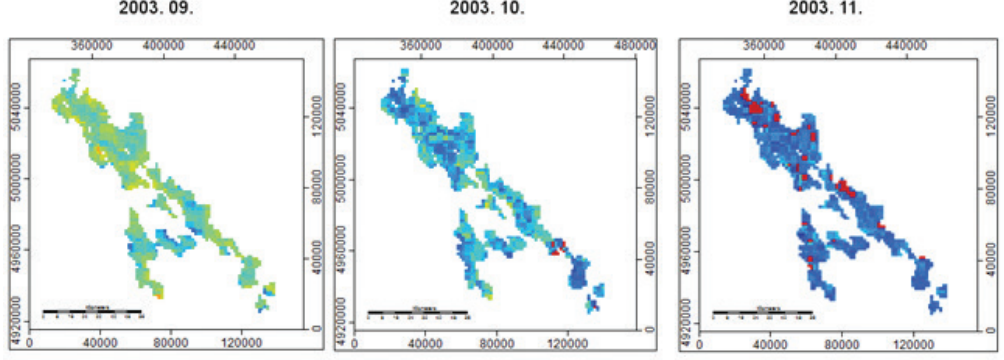

FIGURE 5. Changes of monthly FAPAR for the segment of C1 beech ecosystem during 2003 
TABLE 2. Statistics of the main topographic and climatic properties of the beech ecosystems

ELEVATION

\begin{tabular}{|c|c|c|c|c|c|c|c|c|c|c|c|c|c|}
\hline Ecosystem & B1 & C1 & C3 & C4 & D1 & D2 & D3 & D4 & D5 & D6 & D7 & H1 & $\mathrm{H} 2$ \\
\hline No samples & 407 & 2354 & 34 & 186 & 1648 & 317 & 55 & 841 & 40 & 1377 & 792 & 1219 & 79 \\
\hline Min & 596.1 & 245.8 & 789.3 & 237.0 & 114.7 & 158.6 & 163.9 & 123.6 & 194.0 & 126.9 & 109.5 & 20.3 & 188.0 \\
\hline Max & 1576 & 1557 & 1198 & 958 & 1316 & 922 & 957 & 1041 & 364 & 1341 & 319 & 1491 & 940 \\
\hline Range & 979 & 1312 & 409 & 721 & 1202 & 764 & 793 & 917 & 170 & 1214 & 210 & 1470 & 752 \\
\hline Average & 1160 & 936 & 1031 & 559 & 672 & 328 & 408 & 252 & 292 & 340 & 181 & 886 & 540 \\
\hline Variance & 8892 & 14688 & 7366 & 10054 & 10640 & 4871 & 10879 & 3562 & 639 & 5391 & 417 & 16567 & 16531 \\
\hline Stdev & 85 & 108 & 68 & 84 & 89 & 59 & 94 & 38 & 25 & 56 & 18 & 108 & 128 \\
\hline \multicolumn{14}{|l|}{ SLOPE } \\
\hline Ecosystem & B1 & C1 & C3 & C4 & D1 & D2 & D3 & D4 & D5 & D6 & D7 & H1 & H2 \\
\hline No samples & 407 & 2354 & 34 & 186 & 1648 & 317 & 55 & 841 & 40 & 1377 & 792 & 1219 & 79 \\
\hline Min & 0.11 & 0.05 & 0.47 & 0.35 & 0.02 & 0.25 & 0.34 & 0.03 & 0.09 & 0.18 & 0.04 & 0.06 & 0.77 \\
\hline Max & 18.98 & 20.93 & 20.02 & 15.50 & 19.86 & 12.92 & 12.28 & 15.94 & 3.86 & 19.37 & 2.85 & 23.03 & 19.68 \\
\hline Range & 18.87 & 20.89 & 19.55 & 15.15 & 19.83 & 12.67 & 11.94 & 15.91 & 3.77 & 19.19 & 2.81 & 22.97 & 18.91 \\
\hline Average & 6.81 & 5.52 & 8.03 & 5.83 & 4.72 & 3.03 & 3.79 & 1.99 & 1.45 & 2.91 & 0.78 & 6.27 & 6.89 \\
\hline Variance & 7.36 & 7.44 & 2.77 & 4.60 & 6.80 & 2.08 & 5.19 & 1.33 & 0.36 & 1.94 & 0.13 & 7.24 & 16.32 \\
\hline Stdev & 2.48 & 2.49 & 1.10 & 1.66 & 2.19 & 1.20 & 2.04 & 0.79 & 0.60 & 1.07 & 0.32 & 2.35 & 3.90 \\
\hline \multicolumn{14}{|l|}{ ASPECT } \\
\hline Ecosystem & B1 & C1 & C3 & C4 & D1 & D2 & D3 & D4 & D5 & D6 & D7 & H1 & $\mathrm{H} 2$ \\
\hline No samples & 407 & 2354 & 34 & 186 & 1648 & 317 & 55 & 841 & 40 & 1377 & 792 & 1219 & 79 \\
\hline Min & 1.3 & 0.3 & 7.9 & 0.5 & 0.1 & 0.2 & 7.5 & 0.4 & 8.2 & 0.1 & 0.0 & 1.8 & 1.1 \\
\hline Max & 358.5 & 359.6 & 358.7 & 359.0 & 359.8 & 359.3 & 343.3 & 359.7 & 352.3 & 359.9 & 359.9 & 360.0 & 351.7 \\
\hline Range & 357.2 & 359.3 & 350.8 & 358.5 & 359.7 & 359.1 & 335.8 & 359.3 & 344.2 & 359.8 & 359.9 & 358.2 & 350.5 \\
\hline Average & 167.8 & 178.0 & 142.0 & 170.7 & 164.3 & 168.7 & 145.3 & 159.8 & 177.1 & 157.4 & 183.2 & 184.5 & 94.9 \\
\hline Variance & 5099.5 & 10691.6 & 3450.5 & 8980.2 & 8497.1 & 6801.7 & 3857.6 & 8483.4 & 8595.9 & 7769.3 & 8601.0 & 5081.2 & 8738.3 \\
\hline Stdev & 59.3 & 97.6 & 37.9 & 76.5 & 82.2 & 69.9 & 61.3 & 78.3 & 86.0 & 76.0 & 85.4 & 58.2 & 92.2 \\
\hline Facet & $\mathrm{S}$ & $\mathrm{S}$ & SE & $\mathrm{S}$ & $\mathrm{S}$ & $\mathrm{S}$ & SE & $\mathrm{S}$ & $\mathrm{S}$ & SE & $\mathrm{S}$ & $S$ & E \\
\hline \multicolumn{14}{|c|}{ TEMPERATURE } \\
\hline Ecosystem & B1 & C1 & C3 & C4 & D1 & D2 & D3 & D4 & D5 & D6 & D7 & H1 & $\mathrm{H} 2$ \\
\hline No samples & 403 & 2345 & 35 & 188 & 1661 & 325 & 56 & 841 & 43 & 1382 & 796 & 1232 & 78 \\
\hline Min & 2.6 & 2.1 & 4.8 & 5.3 & 4.5 & 5.2 & 6.1 & 4.8 & 9.2 & 4.5 & 8.9 & 3.0 & 5.3 \\
\hline Max & 10.4 & 10.6 & 8.4 & 9.8 & 10.8 & 10.5 & 10.4 & 10.6 & 10.1 & 10.8 & 10.6 & 13.5 & 10.7 \\
\hline Range & 7.8 & 8.5 & 3.6 & 4.5 & 6.3 & 5.3 & 4.3 & 5.8 & 0.9 & 6.3 & 1.7 & 10.5 & 5.4 \\
\hline Average & 6.2 & 6.8 & 6.5 & 7.9 & 8.2 & 9.3 & 9.1 & 9.7 & 9.6 & 9.4 & 9.9 & 7.9 & 8.4 \\
\hline Variance & 0.4 & 0.5 & 0.3 & 0.3 & 0.4 & 0.2 & 0.4 & 0.2 & 0.0 & 0.2 & 0.0 & 0.7 & 0.6 \\
\hline Stdev & 0.5 & 0.6 & 0.4 & 0.5 & 0.6 & 0.4 & 0.6 & 0.3 & 0.1 & 0.4 & 0.1 & 0.7 & 0.8 \\
\hline \multicolumn{14}{|c|}{ PRECIPITATION } \\
\hline Ecosystem & B1 & C1 & C3 & C4 & D1 & D2 & D3 & D4 & D5 & D6 & D7 & H1 & H2 \\
\hline No samples & 403 & 2345 & 35 & 188 & 1661 & 325 & 56 & 841 & 43 & 1382 & 796 & 1232 & 78 \\
\hline Min & 1227 & 1183 & 1538 & 887 & 912 & 754 & 945 & 739 & 854 & 787 & 816 & 1145 & 1396 \\
\hline Max & 3444 & 3234 & 2643 & 1343 & 2816 & 1930 & 1904 & 1581 & 1101 & 2300 & 917 & 3286 & 2107 \\
\hline Range & 2216 & 2050 & 1105 & 457 & 1904 & 1175 & 959 & 842 & 247 & 1513 & 101 & 2141 & 710 \\
\hline Average & 2034 & 1696 & 2042 & 1073 & 1541 & 950 & 1359 & 968 & 987 & 1166 & 863 & 1686 & 1740 \\
\hline Variance & 14514 & 25321 & 16144 & 1165 & 14746 & 803 & 3234 & 934 & 145 & 2427 & 99 & 20233 & 10401 \\
\hline Stdev & 79 & 109 & 93 & 27 & 91 & 22 & 45 & 17 & 11 & 29 & 8 & 100 & 98 \\
\hline \multicolumn{14}{|c|}{ ELLENBERG'S DROUGHT INDEX } \\
\hline Ecosystem & B1 & C1 & C3 & C4 & D1 & D2 & D3 & D4 & D5 & D6 & D7 & H1 & $\mathrm{H} 2$ \\
\hline No samples & 115 & 1246 & 41 & 66 & 889 & 163 & 52 & 393 & 23 & 798 & 499 & 668 & 62 \\
\hline Min & 3.82 & 3.63 & 4.41 & 12.29 & 4.87 & 14.54 & 8.04 & 8.84 & 16.24 & 5.91 & 21.03 & 4.51 & 8.31 \\
\hline Max & 13.63 & 16.95 & 14.26 & 19.33 & 21.39 & 26.28 & 21.24 & 27.90 & 23.05 & 25.77 & 24.97 & 18.66 & 18.86 \\
\hline Range & 9.81 & 13.32 & 9.85 & 7.04 & 16.52 & 11.73 & 13.20 & 19.06 & 6.81 & 19.86 & 3.93 & 14.15 & 10.56 \\
\hline Average & 7.38 & 9.01 & 7.56 & 17.17 & 12.47 & 20.51 & 15.25 & 19.47 & 20.73 & 17.95 & 23.34 & 11.28 & 12.89 \\
\hline Variance & 4.11 & 6.76 & 4.52 & 2.73 & 5.42 & 5.83 & 19.05 & 13.44 & 5.69 & 13.38 & 0.00 & 6.33 & 8.47 \\
\hline Stdev & 2.03 & 2.60 & 2.13 & 1.65 & 2.33 & 2.41 & 4.36 & 3.67 & 2.39 & 3.66 & 0.00 & 2.52 & 2.91 \\
\hline
\end{tabular}


predominant soil type, which is dry and relatively shallow molic, rendzic leptosol (rendzina). Overall temperature amplitude for the common beech is between $2.1-13.5^{\circ} \mathrm{C}$ and precipitation amplitude between 754-3444 mm. There is evidence of a gradual increase of the average temperatures and evidence of more alternating but decreasing trend of average precipitation along bioclimatic gradients (B-C-D). The estimated maximal value of the Ellenberg quotient of 27.9 represents the xeric limit for the beech in the continental region. However, values of the Ellenberg quotient in the Sub-mediterranean ecosystem $\mathrm{H} 1$ do not exceed 18.7 that are well below continental limits.

\section{Photosynthetic Activity (FAPAR)}

Figure 7 presents the average values of photosynthetic activity of 13 common beech ecosystem types for the period March-November. The estimated range of average FAPAR is from minimal 0.43 (B1) to maximal 0.55 (C4). FAPAR is decreasing in ecosystems on higher altitudes $(\mathrm{B} 1, \mathrm{C} 1, \mathrm{C} 3)$ and the Mediterranean (H1). Ecosystem B1 (Subalpine beech forest) has the lowest activity at the upper limit of beech altitudinal zone in Dinaric Alps. On the other hand, the highest photosynthetic activity can be found in ecosystems in the coline belt, D1-D7 (Mountain beech forests), at low to medium altitudes. Overall differences between series of mean FAPAR for an 8 year period, 1998-2005, prove high significance at $\mathrm{p}<0.001$ (AOV test). Multiple comparisons between groups (Figure 8) provide insight into significance amongst ecosystem pairs. The performed test confirms overall differences amongst ecosystems included in bioclimatic hierarchy. However, there is proven significance on intra-bioclimatic level, most obvious between beech - fir mixed forests in the Dinaric and Pannonian region. Productivity of beech and fir forests in the continental Pannonian hills, C4 (Pannonian beech-fir forest) significantly exceeds productivity of the beech and fir forests in the Dinaric Alps, C1 and C3 (Dinaric beech-fir forest). Differences
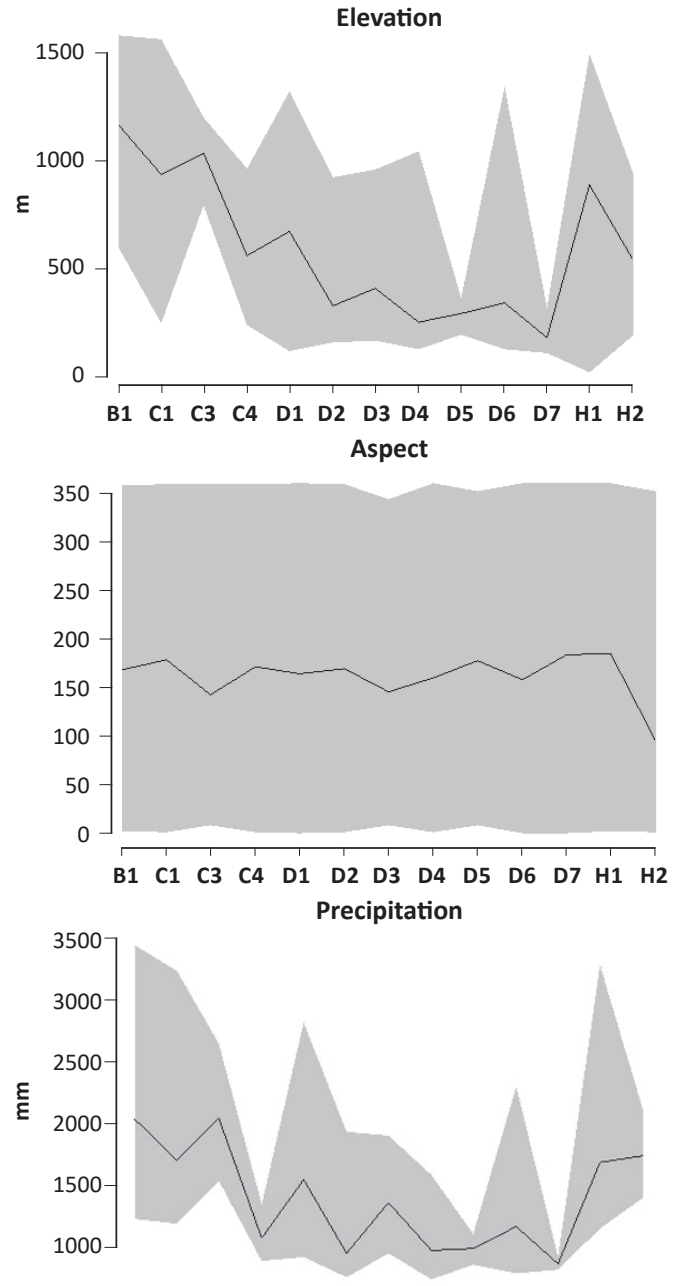

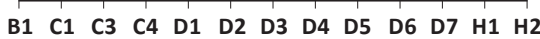
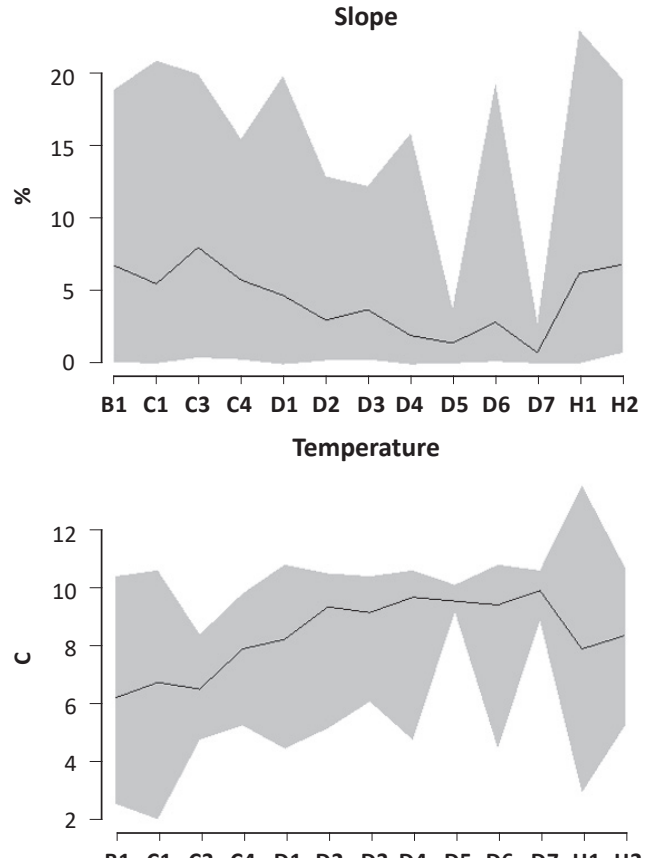

B1 C1 C3 C4 D1 D2 D3 D4 D5 D6 D7 H1 H2

Ellenberg

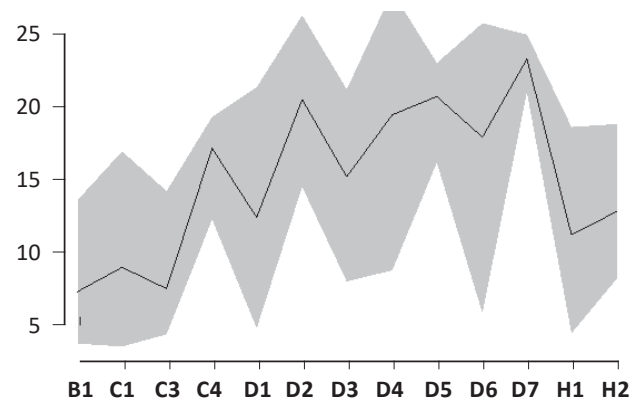

FIGURE 6. Preferential environmental properties and limits of the common beech ecosystem types 
inside bioclimatic group D, mountain beech forest vegetation type (Montane beech forest) can be attributed to edaphic factors. Higher productivity is found in relatively deeper soils such as rendzic leptosol (deep rendzina on unconsolidated material), luvisol and dystric cambisol. There is also a noticeable difference amongst types $\mathrm{H} 1$ and $\mathrm{H} 2$ inside thermophylic beech vegetation group where $\mathrm{H} 1$, the sub-Mediterranean beech forest, has one of the lowest productivity and $\mathrm{H} 2$, termophylic continental beech forest is very near to the most productive ecosystems. More intrinsic insight into ecosystems performance can be obtained from the phenological pattern based on monthly FAPAR average series (Figure 9). Ecosystems follow a general pattern of seasonality with vegetation onset in May and rapid inclination of photosynthetic activity during June until maximal values in July. From July to September there is a prevailing stage of maximal photosynthetic activity of forests. Cessation of maximal activity

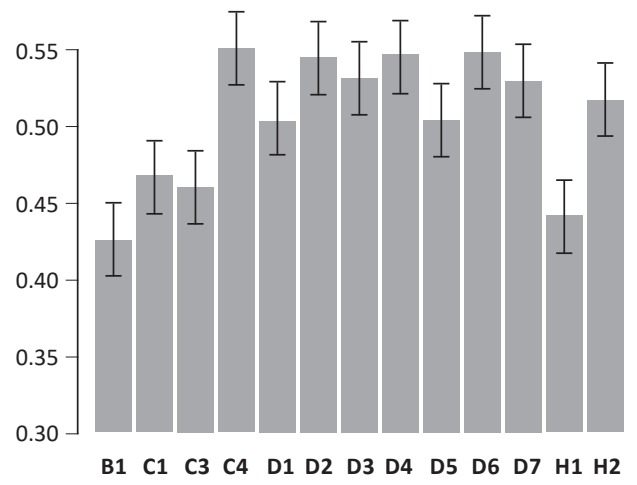

FIGURE 7. Average annual values of FAPAR (March-November) and the onset of senescence is in October and a sharp decline of activity in November. Apart from this general seasonal pattern there is a visible shift in phenology along bioclimatic range D-C-B. Seasonal distribution of FAPAR swings in absolute values from $D$ to $B$, retaining a similar shape. The impact of summer drought in the Mediterranean is evident in ecosystem $\mathrm{H} 1$ through a more rapid reduction of photosynthetic activity in the mid-season.

More pronounced insight into vegetation timing can be obtained from the contrast of monthly slices of FAPAR (Figure

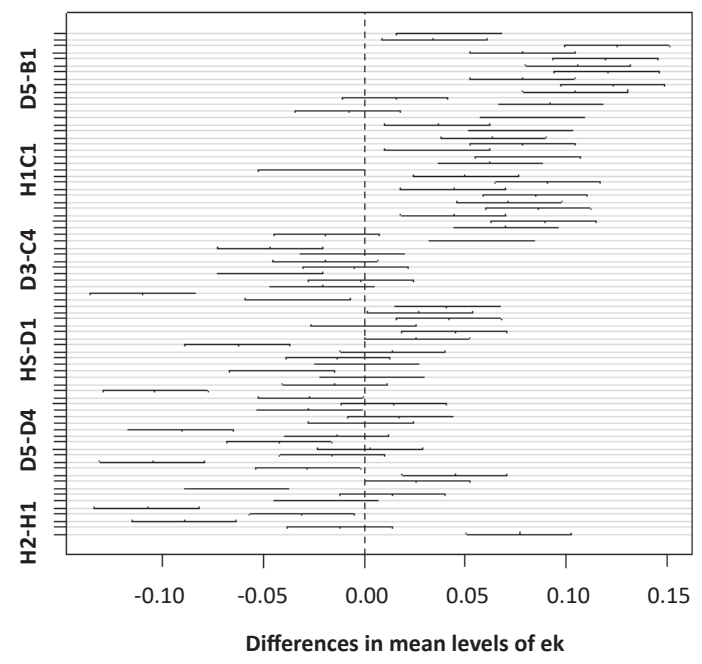

FIGURE 8. Multiple comparisons of yearly differences amongst ecosystems provided by Tukey HSD test

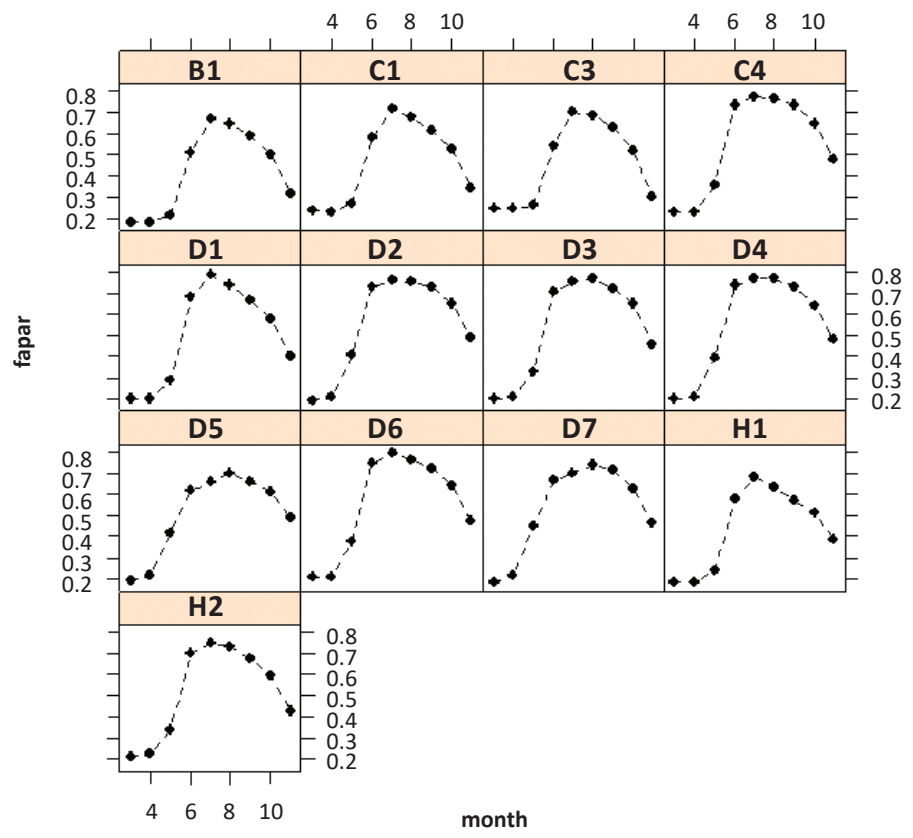

FIGURE 9. The shapes of seasonal FAPAR based on 8 year monthly averages 
10). There is a small but noticeable increase in FAPAR during vegetation dormancy (March-April), a consequence of activity of evergreen silver fir in mixed beech-fir forests $(C 1, C 3, C 4)$. Also, there is evident of a gradual boost of vegetation in May, along bioclimatic gradient $\mathrm{D}-\mathrm{C}-\mathrm{B}$, earliest in $\mathrm{D}$ and the latest in $\mathrm{B}$. On the contrary, the start of the senescence period is in November, the earliest in B and the latest in D.

\section{Intra-Seasonal Variations and Ecosystem Responses}

Figure 11 presents normalized variations of monthly FAPAR values (z-scores) for the observed period (1998-2005). These deviations are mainly influenced by climatic variations of which the most pronounced events were drought and a heat wave in 2003 and an extremely wet 2005 . All ecosystems show the possibility to rapidly adapt their photosynthetic activity in a positive or negative way depending on more or less suitable climatic conditions. From the presented scores, insight into the behaviour of ecosystems under a particular climatic extreme can be noted. The drought and heat wave of 2003 had less influence on FAPAR inside bioclimatic zones C and B. In conditions of excessive precipitation in 2005, only a few ecosystems show a more positive response (C4, D2, D4 and D7). On the contrary, ecosystems B1, C1 and C3 show reduced activity throughout 2005 with the exception of springtime.

Figure 12 presents calculated coefficients of variation for consecutive months which indicates the time or stage with the most pronounced fluctuations of FAPAR. The beech exhibits the highest responses to external anomalies during vegetation onset in spring. Variations gradually recede towards mid season and gradually increase at the beginning of the senescence period. This proves that the beech has very conservative and robust behaviour in relation to climate anomalies during the mid-season with maximal productivity. The highest variations of FAPAR during spring and autumn indicate a specific trait of the common beech in that it can seasonally adjust the kickoff and cessation of its phenology, responding with an earlier onset of vegetation to favourable (warm) climatic settings or forcing a premature drop in productivity during water shortages and drought, while retaining relatively constant FAPAR in the mid-season. Less pronounced variations during the onset of growth were characteristic for $\mathrm{C} 1$ and C3 (mixed beech-fir forest) because of the possible stable influence of the silver fir. There is evidence of a gradual shift in the maximal variations amongst ecosystem types so that maximal variations in B1, C1 and C3 (higher altitudes of the Dinaric Alps) occur in June, in most of the ecosystems inside bioclimates $D$ and $\mathrm{H}$ (except D5 and D7) in May and D5 and D7, in the lowest positions, in April and March.

Seasonal variations of FAPAR can be applied in a more suitable way to obtain more perceptive insight into the adaptive capacity of beech ecosystems by calculating resilience metrics (resistance, recovery, resilience and relative resilience). Resilience metrics provide a quantitative insight into the intrinsic capacity and responses of beech ecosystems to climate alterations (Fig. 12). The highest resistance is distinctive for ecosystem B1 followed by the group of ecosystems $\mathrm{C} 1, \mathrm{C} 3, \mathrm{H} 1$ and $\mathrm{D} 1$. On the contrary, ecosystems inside bioclimate D (except D1) exhibit the lowest resistance. Recovery, as an inverse of resistance (ecosystems with a smaller drop of FAPAR also have lower recovery), show a relatively opposite picture with pronounced ecosystems D5 and D7. Consequently, the ecosystem with the highest resilience is ecosystem B1, followed by the group of ecosystems inside bioclimate $\mathrm{C}$ together with $\mathrm{D} 1, \mathrm{D} 3$ and $\mathrm{H} 1$. The lowest resilience was shown in ecosystems inside bioclimatic group $D$. With respect to relative resilience, ecosystems exhibit a very heterogenic image where only ecosystems D5 and D7 deviate more from others.

\section{DISCUSSION}

Remote sensing FAPAR, with a spatial resolution of around 1 $\mathrm{km}$, presents vegetation indices suitable for assessment of land surface phenology and climatic anomalies on a global or European scale [25]. By performing a global assessment, information about vegetation cover is usually generalized and simplified to a few broad vegetation or land-cover types. By integrating FAPAR and country scale forest ecosystem classification, the power of FAPAR seasonal sensitivity can be extended to provide dynamic linkage with the range of static auxiliary data incorporated into ecosystem structure. With this respect, the results of analysis of auxiliary topographic and climatic features of determined forest types serve to define the environmental conditions and their limits in a more comprehensive quantitative manner. Additionally, supported information can be used as a quantitative mean for evaluation of an empirical classification system such as the forest typological approach in Croatia. This refers primarily to scientific works and surveys in the last 80 years by Horvat $[25,26]$, Horvat, Glavač and Ellenberg [27], Bertović and Lovrić [28], Cestar et al. [29-31], Pelcer and Medvedović [32], Rauš and Vukelić [33], Trinajstić [34], Trinajstić and Franjić [35], Vukelić and Rauš [36], Vukelić and Baričević [37], Pernar and Bakšić [13] and Mesić [38].

\section{Basic Environmental Properties of Beech Forest Types}

The obtained results clearly support determined vertical differentiation of the beech bioclimates and ecosystem types over the particular altitudinal ranges, covariant with temperature and precipitation gradients. Based on the yearly average FAPAR, the most productive environmental niches are located in bioclimate $D$, the area of mountainous and sub mountainous beech forests, in the hillsides of the mountainous continental belt from 181 to $672 \mathrm{~m}$ (ecosystem averages). In this mountainous zone with temperature averages of $8.2-9.9^{\circ} \mathrm{C}$ and yearly precipitation of $863-1541 \mathrm{~mm}$, the beech forms mostly pure homogeneous stands because of its high competitiveness. At higher altitudes, the beech appears with the silver fir forming mixed beech-fir forests (bioclimate C). The average altitudes for beech - fir mixed forests in the Dinaric zone is $936 \mathrm{~m}$ (C1), $1031 \mathrm{~m}$ (C3) and in Pannonian zone $559 \mathrm{~m}$ (C4). Respective average temperatures are $6.5^{\circ} \mathrm{C}(\mathrm{C} 1), 6.8^{\circ} \mathrm{C}(\mathrm{C} 3)$ and $7.9^{\circ} \mathrm{C}$ (C4) and average precipitation amounts to $1696 \mathrm{~mm}$ (C1), $2042 \mathrm{~mm}$ (C3) and $1073 \mathrm{~mm}$ (C4). Above this zone, in the highest altitudinal range, the subalpine beech forest type (B1) appears forming pure stands with characteristic bended trunks due to the long lasting snow on steep slopes. This type prevails at average altitudes of $1160 \mathrm{~m}$, with an average temperature of $6.2^{\circ} \mathrm{C}$ and a precipitation amount of $2034 \mathrm{~mm}$. In the Mediterranean littoral zone, the only beech ecosystem, $\mathrm{H} 1$, exists at relatively higher altitudes $(886 \mathrm{~m})$, with an average temperature of $7.9^{\circ} \mathrm{C}$ and precipitation of $1686 \mathrm{~mm}$.

Photosynthetic Activity (FAPAR) of Beech Ecosystems

FAPAR [39], used as cumulative metrics, presents a proxy for assessing forest productivity (gross primary production). The 


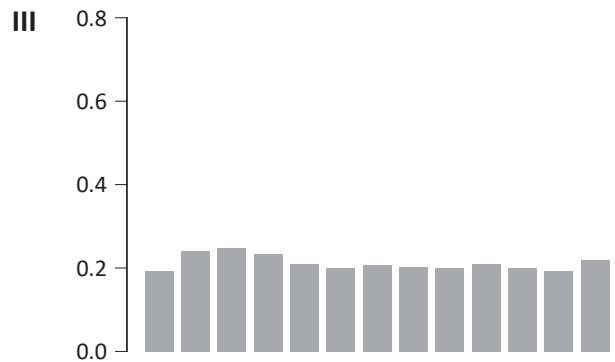

B1 C1 C3 C4 D1 D2 D3 D4 D5 D6 D7 H1 H2

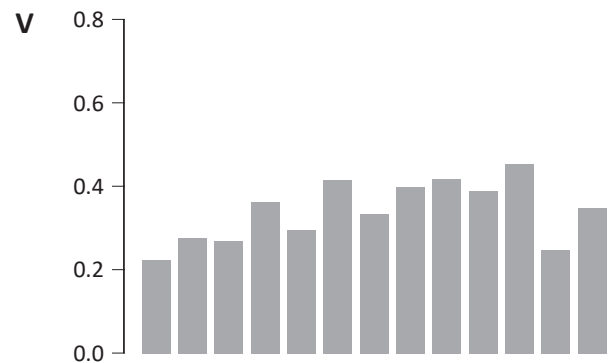

B1 C1 C3 C4 D1 D2 D3 D4 D5 D6 D7 H1 H2

VII

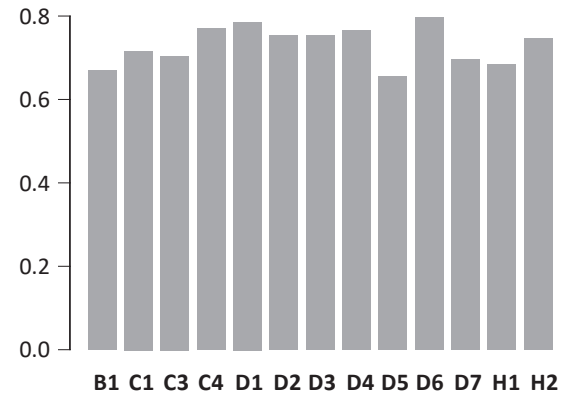

IX

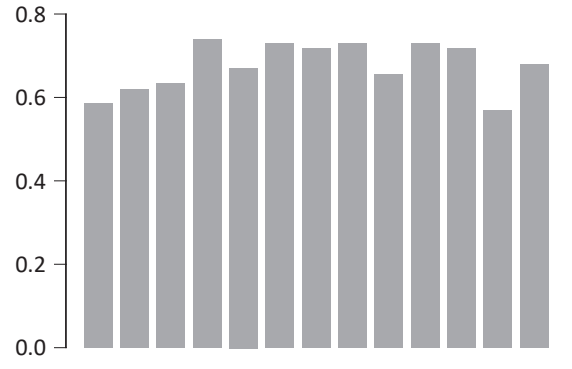

B1 C1 C3 C4 D1 D2 D3 D4 D5 D6 D7 H1 H2

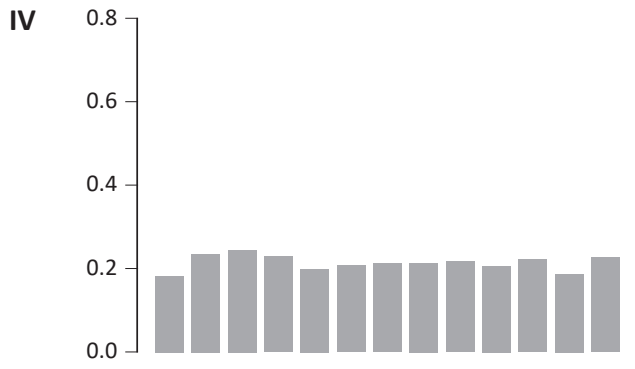

B1 C1 C3 C4 D1 D2 D3 D4 D5 D6 D7 H1 H2

VI

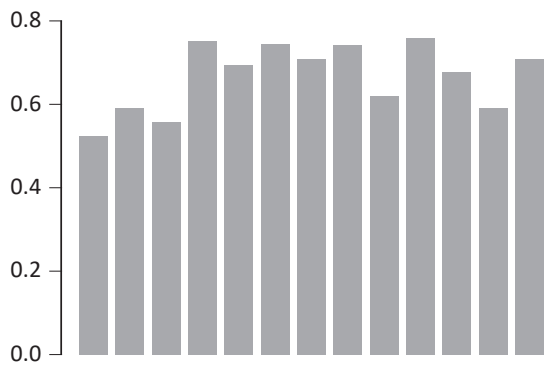

B1 C1 C3 C4 D1 D2 D3 D4 D5 D6 D7 H1 H2

VIII

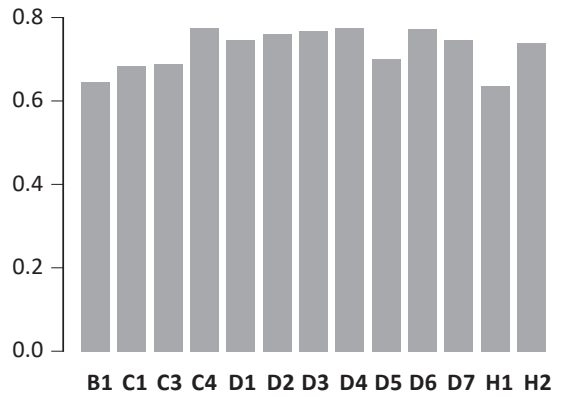

X

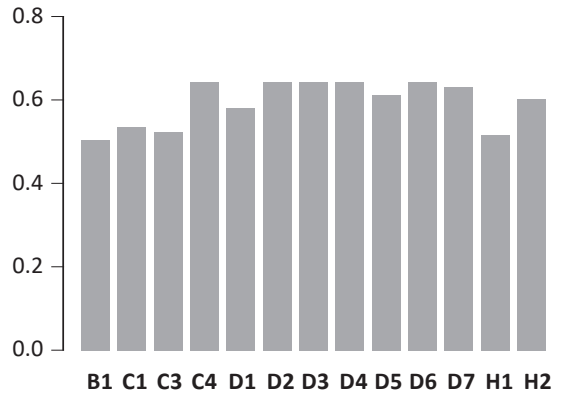

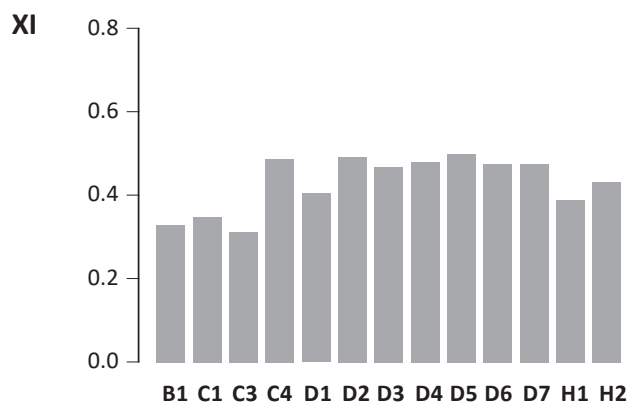




\section{Z scores}
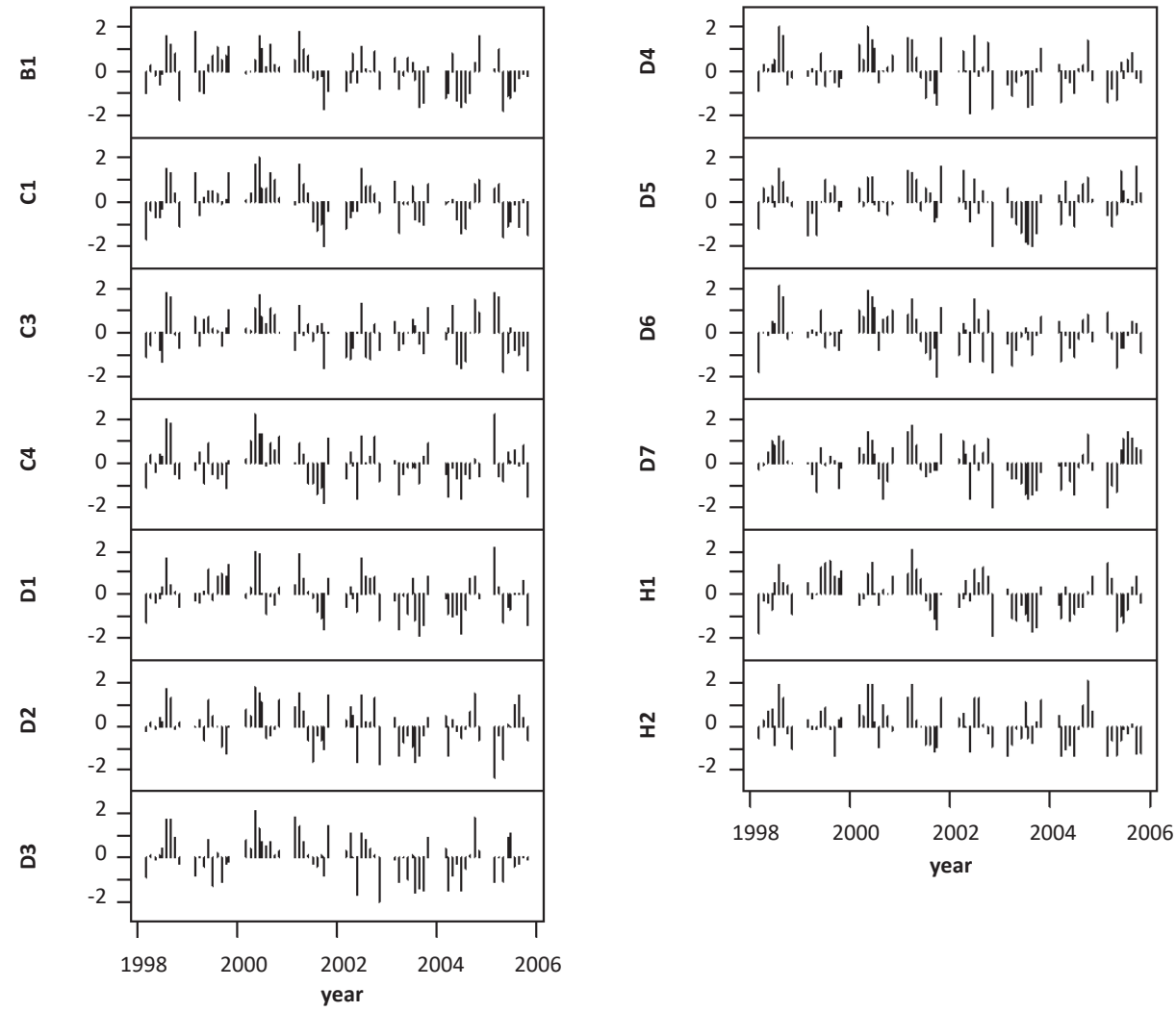

FIGURE 11. Normalized variations ( $z$ - scores) of FAPAR during the observation period

results of average FAPAR determine differences in the productivity of beech ecosystems in relation to climate and topography including edaphic factors at the intra bioclimatic level. The overall productivity of common beech forests declines as the altitude increases and towards xeric environmental margins. The common property of soils (rendzic leptosol on unconsolidated material, luvisol, cambisol), in the most productive beech forest types is intermediate to a larger depth (approximate $\min 60 \mathrm{~cm}$ ), free drainage capability and a very broad range of soil chemical and physical characteristics that is in accordance with Peters [40] and Sanders et al. [41]. There is also evidence that soil properties provide some limitations in productivity. Beech stands on very shallow soils such as cambisols and rendzic leptosol and partly waterlogged soils such as gleyic luvisol show lower values of average FAPAR of all types in the mountainous beech zone (D). The possible influence of edaphic parameters is even more detectible in mixed beech - silver fir forests inside bioclimate $\mathrm{C}$. Very large differences in productivity of mixed stands (C1, C3, C4), in favour of the continental Panonnian ecosystem type (C4), could be attributed to more deeper and productive soils (i.e. dystric cambisol in relation to shallow folic cambisol and mollic leptosol).

There is a common trait that altitude has an impact on the duration of the vegetation period as can be corroborated in the regional phenology studies of the common beech $[42,43]$. The earliest onset of the spring phenological phases is observed in the lowest-lying sites and the latest onset in the uppermost sites. The dynamics of the autumn phenological phases had an opposite trend compared to the spring phenophases. This is also evident in our study through an earlier and gradual increase of FAPAR in May and June across bioclimatic vertical zones (D-C-B). The impact of altitude in the cessation of vegetation in October and November is not so pronounced. It is obvious that in the mid vegetation season (July, August), ecosystem productivity retains more constant values than in the onset and senescence periods. This indicates that during mid-season, the peak production of beech ecosystems is relatively uniform across the altitudinal gradient, with small differences related most probably to beech stand structural characteristics. A higher annual productivity in the common beech at lower altitudes can be associated more to the prolonged period of growth than the peak productivity potential of forests by themselves. Ergo, growth duration is most possibly modified by the climatic variations during springtime, during a period of the highest phenological sensitivity that is reflected through the highest FAPAR alternations. Generally, an earlier growth onset is due to the early spring warming and the delay of onset due to the spring chill. An accepted understanding of the impact of global 
warming on phenology, given by Rötzer and Chmielewski [44], is that vegetation onset spreads southward at a rate of about 2 days per degree of latitude, the rate of change of the growth season length for forests is in a range of 6.4-6.7 days per ${ }^{\circ} \mathrm{C}$. Warmer spring temperatures have advanced flowering dates by about 4 days per $1{ }^{\circ} \mathrm{C}$ and leaf unfolding by about $3.2-3.6$ days per $1^{\circ} \mathrm{C}$ in Europe. As the possible outcome, a recent dendrochronological study of Tegel et al. [45] detected an unexpectedly rapid boost of beech growth after 1990 in the southern Balkan Peninsula (Albania, Macedonia) which is contrary to broad expectations of warming induced suppression of forests productivity in their southern Mediterranean limits. The beech is principally sensitive to excessive summer warming (June-September) that causes a water deficiency and drought as is confirmed in regional studies by Dittmar et al. [46], Dittmar and Elling [47], Van der Maaten [48] and Tegel et al. [45].

The results of our study reveal that the beech is very adaptable and opportunistic to newly emerging warming conditions because it can easily drift its vegetation onset earlier in the springtime and thus it is capable of prolonging the growing season and increasing its productivity to some degree. However, the smallest fluctuations of FAPAR during the mid-season (July, August, September) indicate that during this period of maximal productivity, the beech is relatively invariant to climate anomalies. One possible explanation is that the plant available water status of the majority of beech forest soils in mountain areas (with the higher total precipitation and lower average temperatures) is not the limiting factor for growth during this mid phenology stage. The prolonged droughts can cause soil water shortage which results in a decline of productivity and earlier senescence of vegetation in the later stages (October, November) which is obvious due to recurring higher variations of FAPAR in this period. As a consequence, this can contribute to reduced productivity of the beech on an annual scale. In general, according to the provided seasonality of FAPAR variations, it can be concluded that with respect to climatic anomalies, the beech phenology behaves like an intra seasonal teeter, drifting over stable conditions during the mid-season and adapting to opportunities and limitations in springtime and autumn. Warmer conditions in springtime, on the one hand present an opportunity, but on the other, their extension throughout the year produces limitations for productivity in later stages of growth.

In the scenarios of the progression of global warming, there is a strong emphasis on the assessment of the future distribution range of beech forests which has been the subject of modelling and regional simulation studies [4-9]. Therefore, an estimation of environmental conditions on the limits of the beech distribution range, prone to many uncertainties, is of huge interest for the forest management. In this study, the boundary conditions of three marginal limits were assessed: upper altitudinal, southeastern continental and the Mediterranean. By applying an ecosystem based approach, beech propagation also in relation to prevailing edaphic conditions in the marginal zones can be discussed, as it is often neglected in climate-vegetation modelling and simulations. Based on the maximal and minimal values of topographic and climatic factors, it can be concluded that the current upper altitudinal limit of the beech in Croatia is 1576 $\mathrm{m}$ with a minimal yearly temperature of $2.2^{\circ} \mathrm{C}$ and maximal

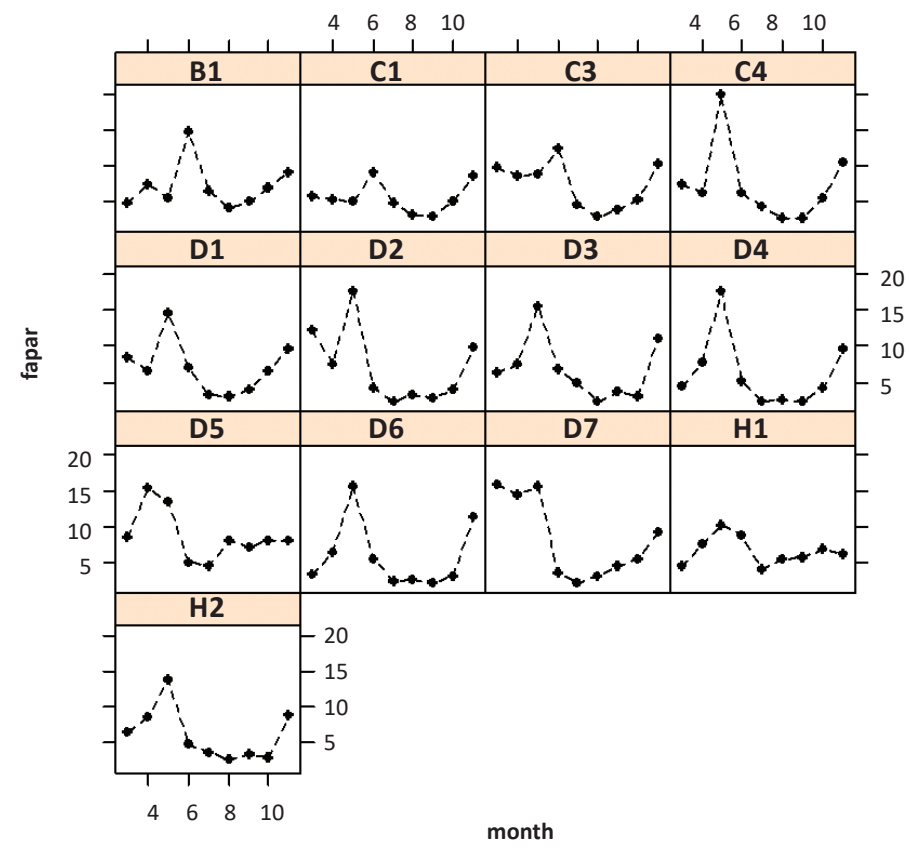

FIGURE 12. Coefficients of variation amongst beech ecosystem types 
precipitation of $3444 \mathrm{~mm}$. This shows that the current beech limit is very close to the upper terrestrial boundary determined by the upper ridges and hilltops of the Dinaric Alps ranging from 1750 to $1831 \mathrm{~m}$. However, a future vertical succession of the common beech in this carstic environment is limited by very shallow soils on hard calcareous substrate and by eroded surfaces with plain rocks. On the other hand, the xeric limits for the beech in the continental region is at the lower slopes with a minimal altitude of $109.5 \mathrm{~m}$ in the Pannonian hills (max altitudes 900-110 m), on the junction with the Pannonian plain (95-115 m). The estimated maximal average temperature limitation for the beech is $10.8^{\circ} \mathrm{C}$ and minimal yearly precipitation is $739 \mathrm{~mm}$, which exceeds the xeric limit of $9.3^{\circ} \mathrm{C}$ and is above the limit of $680 \mathrm{~mm}$ provided by Czúcz et al. [4]. Maximal values of Ellenberg's climate quotient do not exceed values of 27.9 which is below 28.9 [4], the limiting climatic conditions for the beech in Hungary. Productivity (mean annual FAPAR) of ecosystems at the lower boundary is, in general, below the average for the respective bioclimatic group (D) which could be partly attributed to less suitable edaphic conditions. The lowest lying ecosystem D7, (109.5-319 m) appears on seasonally waterlogged soil (gleyic luvisol) and seasonal oversaturation in soils most probably do not represent optimal conditions for beech growth. The seasonal modification of the Mediterranean climate, in particular an alternation of wet and mild winters and hot and dry summers, present constrains for beech distribution and productivity.
According to Maselli et al. [49], productivity of the Mediterranean beech forest is strongly determined by the start of the dry season. The Sub-Mediterranean beech forest ( $\mathrm{H} 1$ ) assessed in this study has one of the lowest productivity. The impact of the summer drought in the Mediterranean can be identified by an earlier decreasing of FAPAR seasonal trajectory starting in August. Sub-Mediterranean beech forest covers the broadest altitudinal range starting from $20 \mathrm{~m}$ above sea level up to $1491 \mathrm{~m}$, mostly on the south-western slopes (average inclination of $6.27 \%$ ) of the littoral flank of the Dinaric Alps. The limiting climatic conditions for the presence of the beech in this region are a mean temperature of $13.5^{\circ} \mathrm{C}$ and 1145 $\mathrm{mm}$ of minimal precipitation. However, the maximal values of $\mathrm{EQ}$ of 18.66 , well below the determined EQ limits for the beech in the continent, provide clues that the generalization of beech climatic limits using simple climatic indices should be undertaken with great care. Lower values of EQ can induce that, in addition to summer drought, edaphic factors such as shallow soils on limestone with a very limited water retention capacity, contribute to seasonal drought exposure which hinders the productivity and progression of beech forests further in the Mediterranean.

Resilience metrics provided in this study present means to quantify and identify various responses of beech ecosystems to climatic anomalies in the period of observation. Indices of resilience are suitable for quantification of the forest responses on an interannual time scale based on some directly measurable environmental

\section{Resistance}

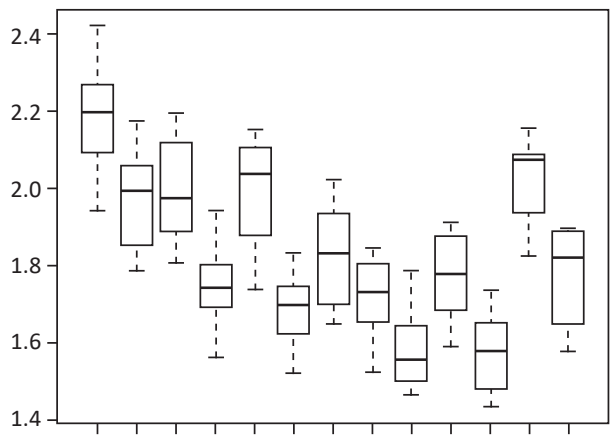

B1 C1 C3 C4 D1 D2 D3 D4 D5 D6 D7 H1 H2

\section{Resilience}

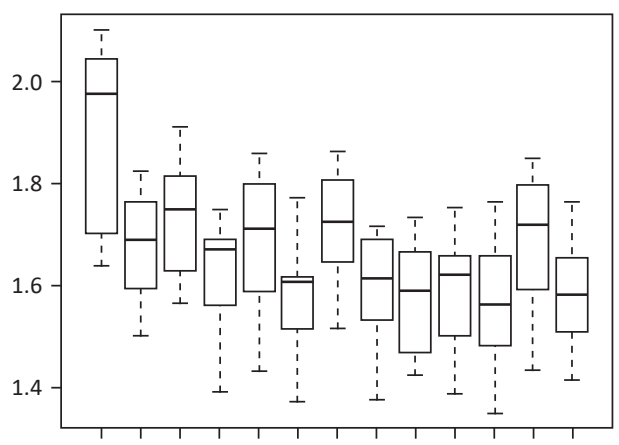

B1 C1 C3 C4 D1 D2 D3 D4 D5 D6 D7 H1 H2

\section{Recovery}

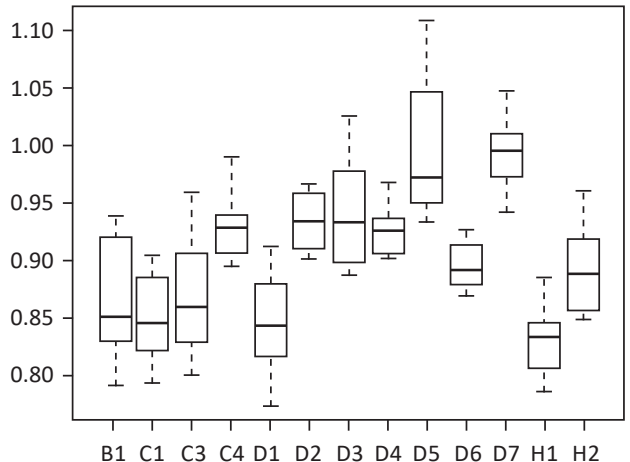

Rel. Resilience

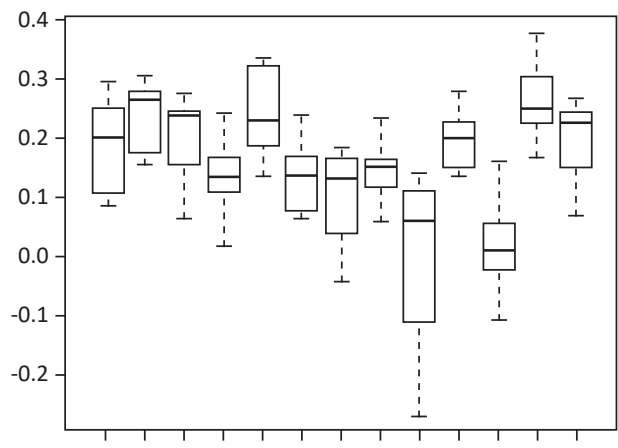

$\begin{array}{lllllllllllllll}\text { B1 C1 } & \text { C3 } & \text { C4 } & \text { D1 } & \text { D2 } & \text { D3 } & \text { D4 } & \text { D5 } & \text { D6 } & \text { D7 } & \text { H1 } & \text { H2 }\end{array}$

FIGURE 13. Resilience metrics based on intra-seasonal FAPAR variations 
tree metrics such as a basal area increment or shoot growth and needle-length in the case of extreme drought conditions. Indices of resilience are mostly based on a single extreme climatic event or pointer years as seen in the studies of Lloret et al. [20], SánchezSalguero et al. [21], Herrero and Zamora [22]. However, applying these indices on an intra-annual scale using a monthly average FAPAR in July as a reference base [23] enables the inclusion of yearly responses for the whole period of observation (1998-2005) and thus, the calculated indices gain more statistical power.

It can be concluded from the calculated indexes of resilience (resistance, recovery, resilience and relative resilience) that the most resilient ecosystems are those occurring on the margins of the beech distribution range that was previously empirically assumed. Highest resistance is exhibited in marginal subalpine (B1) and sub-mediterranean ( $\mathrm{H} 1$ ) beech forests. Highest resistance indicates that their springtime phenology is more suppressed by adverse climatic conditions than in other beech ecosystems. On the other hand, these two marginal ecosystems exhibit the lowest recovery rates. There is an obvious gradual increase in resistance with a rise in altitude and recovery in the opposite way, which presents a possible way of response of the ecosystems to climatic hindering and unbounding. Resilience represents a ratio of the average performance in the second half (August-November) and the first half of the vegetation season (April-June). Above all, the most resilient ecosystem is the subalpine beech (B1). Resilience of the bioclimatic types and ecosystems gradually decline towards lower altitudinal zones. Also, there is evidence of one of the highest resilience of the Sub-Mediterranean beech $(\mathrm{H} 1)$ in comparison to most continental types at low to mid altitudes. At the present, there is confirmed evidence of inherited more adaptive behaviour of beech to droughts in favour of southern populations [50] but looking over a relatively large spatial scale (Germany, Croatia, Bulgaria and Greece). Providing more spatially intensive, ecosystem specific and a confirmatory explanation of beech adaptation, based on aforementioned results could be of the huge benefits for the forest management in the future to cope with the challenges of the global warming.

\section{CONCLUSION}

This study confirms the very adaptive potential of the common beech regarding a broad climatic, topographic and edaphic range.
The common beech can adapt to annual average temperature limits from $2.1^{\circ} \mathrm{C}$ to $13^{\circ} \mathrm{C}$ and precipitation limits from $739 \mathrm{~mm}$ to $3444 \mathrm{~mm}$ which presents an environmental spectrum of $11.4^{\circ} \mathrm{C}$ and $2705 \mathrm{~mm}$ respectively. Photosynthetic activity of beech is reducing towards the marginal limits of its distribution range. The most productive beech forest types are in the continental zone from low to medium altitudes, in medium deep soils. The common beech also shows a broad tolerance to edaphic factors. However, some limitations in productivity are observed on partly waterlogged soils in the lowest continental range and also in shallow soils on limestone in the upper zonal belt. This study also reveals how the specific environmental settings of 13 predefined forest types reflect on common beech productivity and phenology. Unfortunately, because of a relatively coarse spatial resolution of FAPAR $(1.2 \mathrm{~km})$ and an extensive country scale assessment, this study focuses on univariate macroclimatic relations rather than on specific multivariate interactions (i.e. altitude vs. aspect) which are usually more decisive in the formation of suitable microclimatic conditions for the common beech out of the optimal range.

Through assessment of variations in phenology, this study reveals some new insight into the adaptive potential of the beech to emerging climate change. The common beech has great potential to adapt to increasing spring warming by a preterm shift of phenology onset. The beech retains a relatively stable productivity during the peak of phenology in July and August, unrelated to external climatic forcings, so during this period the impact of summer warming could be possibly minor. By extension of droughts in later phenological stages, the beech can respond with preterm cessation of vegetation activity. These findings indicate that the flexibility of phenology timing, especially during springtime, presents one of the important mechanisms of adaptation and resilience of the common beech to global warming. The beech has likewise shown a very opportunistic response potential to earlier spring warming and in particular circumstances could achieve even higher rates of production throughout the season.

\section{Acknowledgment}

This research was carried out under the projects 1924 - AFORENSA (Advanced Forest Ecosystem Services Assessment) and 2831 - CARE (Climate of the Adriatic Region in its global context) both supported by the Croatian Science Foundation.

\section{REFERENCES}

1. BOHN U, GOLLUB G, HETTWER C, WEBER H, NEUHÄUSLOVÁ Z, RAUS T, SCHLÜTER H 2004 Map of the Natural Vegetation of Europe, Scale 1:2.500.000. Interactive CD-ROM, Explanatory Text, Legend, Maps. Landwirtschaftsverlag, Münster, Germany

2. EEA 2007 European forest types, Categories and types for sustainable forest management reporting and policy. EEA Technical report No. 9/2006, European Environment Agency, Copenhagen, Denmark

3. BOLTE A, CZAJKOWSKI T, KOMPA T 2007 The northeastern distribution range of European beech - a review. Forestry 80 (4): 413-429. DOI: http://dx.doi.org/10.1093/ forestry/cpm028
4. CZÚCZ B, GÁLHIDY L, MÁTYÁS C 2011 Present and forecasted xeric climatic limits of beech and sessile oak distribution at low altitudes in Central Europe. Ann For Sci 68 (1): 99-108. DOI: http://dx.doi.org/10.1007/s13595011-0011-4

5. KRAMER K, DEGEN B, BUSCHBOM J, HICKLER T, THUILLER W, SYKES MT, DE WINTER W 2010 Modelling exploration of the future of European beech (Fagus sylvatica L.) under climate change - Range, abundance, genetic diversity and adaptive response. For Ecol Manag 259 (11): 2213-2222. DOI: http://dx.doi.org/10.1016/i. foreco.2009.12.023 
6. MÁTYÁS CS, BERKI I, CZUCZ B, GALOS B, MORICZ N, RASZTOVITS E 2010 Future of Beech in Southeast Europe from the Perspective of Evolutionary Ecology. Acta Silv Lign Hung 6: 91-110

7. STOJANOVIĆ DB, KRŽIČ A, MATOVIĆ B, ORLOVIĆ $S$, DUPUTIE A, DJURDJEVIĆ V, GALIĆ Z, STOJNIĆ S 2013 Prediction of the European beech (Fagus sylvatica L.) xeric limit using a regional climate model: An example from southeast Europe. Agr For Meteorol 176: 94-103. DOI: http://dx.doi.org/10.1016/i.agrformet.2013.03.009

8. RASZTOVITS E, MÓRICZ N, BERKI I, PÖTZELSBERGER E, MÁTYÁS CS 2012 Evaluating the performance of stochastic distribution models for European beech at low-elevation xeric limits. Időjárás (Quarterly Journal of the Hungarian Meteorological Service) 116 (3): 173-194

9. RASZTOVITS E, BERKI I, MÁTYÁS CS, CZIMBER K, PÖTZELSBERGER E, MÓRICZ N 2014 The incorporation of extreme drought events improves models for beech persistence at its distribution limit. Ann For Sci 71 (2): 201210. DOI: http://dx.doi.org/10.1007/s13595-013-0346-0

10. BRUS R 2010 Growing evidence for the existence of glacial refugia of European beech (Fagus sylvatica L.) in the southeastern Alps and north-western Dinaric Alps. Period Biol 112 (3): 239-246

11. IBISCH P 2014 Research and Development project European World Heritage Beech Forests, FKZ 3512821100 Final Project Report. Centre for Econics and Ecosystem Management, Eberswalde URL: https://www.bfn.de/ fileadmin/BfN/internationalernaturschutz/Dokumente/ FG 123/Report EUROWEBU bf final.pdf (19 November 2015)

12. GRAČANIN M 1950 Typological investigations of vegetation and soil as a basis for land classification and evaluation. Transactions of International Congress of Soil Science 11: 1-3

13. PERNAR N, BAKŠIĆ D 2003 The soils of beech forests. In: Matić S, Gračan J, Anić I, Dundović J (eds) Common beech (Fagus sylvatica L.) in Croatia. Academy of Forestry Sciences, Zagreb, Croatia, pp 57-71

14. THORNTWAITE CW 1948 An approach toward a rational classification of climate. Geogr Rev 38 (1): 55-94. DOI: http://dx.doi.org/10.2307/210739

15. ZANINOVIĆ K, GAJIĆ-ČAPKA $M$, PERČEC TADIĆ $M$ 2008 Climate atlas of Croatia 1961-1990, 1971-2000. Meteorological and Hydrological Service, Zagreb, Croatia, 200 p. URL: http://klima.hr/razno/publikacije/klimatski atlas hrvatske.pdf (19 November 2015)

16. GAJIĆ-ČAPKA M., CINDRIĆ K, PASARIĆ Z 2014 Trends in precipitation indices in Croatia, 1961-2010. Theor Appl Climatol 121 (1): 167-177. DOI: http://dx.doi.org/10.1007/ s00704-014-1217-9

17. VUKELIĆ J, BARIČEVIĆ D 2003 Forest communities of common beech in Croatia. In: Matić S, Gračan J, Anić I, Dundović J (eds) Common beech (Fagus sylvatica L.) in Croatia. Academy of Forestry Sciences, Zagreb, Croatia, pp 87-123

18. ELLENBERG H 1988 Vegetation ecology of Central Europe, 4th ed. Cambridge University Press, Cambridge, UK, $756 \mathrm{p}$

19. GOBRON N, PINTY B, AUSSEDAT O, CHEN JM, COHEN WB, FENSHOLT R, GOND V, HUEMMRICH KF, et al. 2006 Evaluation of fraction of absorbed photosynthetically active radiation products for different canopy radiation transfer regimes: methodology and results using joint research center products derived from SeaWiFS against ground-based estimations. J Geophys Res - Atmos 111 (D13). DOI: http://dx.doi.org/10.1029/2005JD006511
20. LLORET F, KEELING EG, SALA A 2011 Components of tree resilience: effects of successive low-growth episodes in old ponderosa pine forests. Oikos 120 (12): 1909-1920. DOI: http://dx.doi.org/10.1111/i.1600-0706.2011.19372.x

21. SÁNCHEZ-SALGUERO R, CAMARERO JJ, DOBBERTIN M, FERNÁNDEZ-CANCIO A, VILÀ-CABRERA A, MANZANEDO RD, ZAVALA MA, NAVARRO-CERRILLO RM 2013 Contrasting vulnerability and resilience to drought-induced decline of densely planted vs. natural rear-edge Pinus nigra forests. For Ecol Manag 310: 956-967. DOI: http://dx.doi. org/10.1016/j.foreco.2013.09.050

22. HERRERO A, ZAMORA R 2014 Plant responses to extreme climatic events: a field test of resilience capacity at the southern range edge. PLOS ONE 9 (1): e87842. DOI: http:// dx.doi.org/10.1371/journal.pone.0087842

23. PILAS I, MEDVED I, MEDAK J, MEDAK D 2014 Response strategies of the main forest types to climatic anomalies across Croatian biogeographic regions inferred from FAPAR remote sensing data. For Ecol Manag 326: 58-78. DOI: http://dx.doi.org/10.1016/i.foreco.2014.04.012

24. CECCHERINI G, GOBRON N, MIGLIAVACCA M 2014 On the Response of European Vegetation Phenology to Hydroclimatic Anomalies. Remote Sens 6 (4): 3143-3169 DOI: http://dx.doi.org/10.3390/rs6043143

25. HORVAT I 1950 Šumske zajednice Jugoslavije (Forest communities of Yugoslavia). Institut za šumarska istraživanja, Zagreb, Croatia

26. HORVAT I 1963 Šumske zajednice Jugoslavije (Forest communities of Yugoslavia). In: Ugrenović A (ed) Šumarska enciklopedija I (Encyclopedia of forestry I), Leksikografski zavod Miroslav Krleža, Zagreb, Croatia, pp 560-590

27. HORVAT I, GLAVAČ V, ELLENBERG H 1974 Vegetations Südosteuropas. G. Fischer Verlag, Stuttgart, Germany

28. BERTOVIĆ S, LOVRIĆ AŽ 1987 Šumske zajednice Jugoslavije, SR Hrvatska (Forest communities of Yugoslavia, Federal Republic of Croatia). In: Potočić Z (ed) Šumarska enciklopedija II (Encyclopedia of forestry II), Leksikografski zavod Miroslav Krleža, Zagreb, Croatia, pp 395-404

29. CESTAR D, HREN V, KOVAČEVIĆ Z, MARTINOVIĆ J, PELCER Z 1979 Tipološke značajke šuma slavonskog gorja (Typological properties of forests in the Slavonian mountains). Radovi šumarskog instituta - Jastrebarsko (Works - Croatian Forest Research Institute) 39: 1-213

30. CESTAR D, HREN V, KOVAČEVIĆ Z, MARTINOVIĆ J, PELCER Z 1981 Ekološko-gospodarski tipovi šuma na području Moslavačke gore. (Ecological - managerial forest types of Moslavačka gora). Radovi šumarskog instituta Jastrebarsko (Works - Croatian Forest Research Institute) 41: $1-70$

31. CESTAR D, HREN V, KOVAČEVIĆ Z, MARTINOVIĆ J, PELCER Z 1983 Ekološko-gospodarski tipovi područja Bilogore (Ecological - managerial forest types of Bilogora mountain). Radovi šumarskog instituta - Jastrebarsko (Works - Croatian Forest Research Institute) 57: 1-96

32. PELCER Z, MEDVEDOVIĆ J 1988 Kriterien für die Zonierung der subalpinen Buchenwälder im dinarischen Gebirge Kroatiens. Sauteria 4: 21-32

33. RAUŠ Đ, VUKELIĆ J 1991 Synoekologish-vegetative Eingenschaften der Rotbuche (Fagus sylvatica L.) in pannonischen Gebiet Kroatiens. 3-IUFRO Buchensymposium, Zvolen, pp 127-141

34. TRINAJSTIĆ I 1995 Geographical division of forest vegetation of Croatia. Annales Forestales 20 (2): 37-66

35. TRINAJSTIĆ I, FRANJIĆ J 1999 Šume bukve s dlakavim šašem (Carici pilosae - Fagetum Oberdorfer 1957) u vegetaciji Hrvatske (Beech forests with ciliated reed grass (Carici pilosae - Fagetum Obersdorfer 1957) in the vegetation of Croatia). Šumar list 123 (7-8): 311-321 
36. VUKELIĆ J, RAUŠ Đ 1998 Šumarska fitocenologija i šumske zajednice u Hrvatskoj (Phytocenology and forest communities in Croatia). University of Zagreb, Faculty of forestry, Zagreb, Croatia, $310 \mathrm{p}$

37. VUKELIĆ J, BARIČEVIĆ 2002 Novije fitocenološke spoznaje o bukovim šumama u Hrvatskoj (Recent phytocenological findings of beech forests in Croatia). Šumar list 126 (9-10): 439-458

38. MESIĆ Z 2012 Impact of the geomorphological parameters to phenological dynamics in the dominant layer of the beech forest of the western and middle Dinaric Alps. PhD thesis, University of Zagreb, Faculty of Forestry, Zagreb, Croatia, $129 \mathrm{p}$

39. JUNG $M$, VERSTRAETE $M$, GOBRON M, REICHSTEIN $M$, PAPALES D, BONDEAU A, ROBUSTELLI M, PINTY B 2008 Diagnostic assessment of European gross primary production. Global Change Biol 14 (10): 2349-2364 DOI: http://dx.doi.org/10.1111/i.1365-2486.2008.01647.x

40. PETERS R 1997 Beech forests. Geobotany 24, Springer Netherlands, 170 p. DOI: http://dx.doi.org/10.1007/97894-015-8794-5

41. SANDERS T, PITMAN R, BROADMEADOW M 2012 Soil type modifies climate-growth response of beech in Southern Britain. In: Gärtner H, Rozenberg P, Montés P, Bertel O, Helle G, Heinrich I (eds) TRACE - Tree Rings in Archaeology, Climatology and Ecology, Vol. 10. GFZ Potsdam, Scientific Technical Report STR 12/03, Potsdam, Germany, pp 106-110

42. ĆUFAR K, DE LUIS M, SAZ MA, ČREPINŠEK Z, KAJFEŽBOGATAJ L 2012 Temporal shifts in leaf phenology of beech (Fagus sylvatica) depend on elevation. Trees 26 (4): 1091-1100. DOI: http://dx.doi.org/10.1007/s00468-0120686-7

43. SCHEIBER B. JANIK R, SNOPKOVA Z 2013 Phenology ofcommon beech (Fagus sylvatica L.) along the altitudinal gradient in Slovak Republic (Inner Western Carpathians). Journal of Forest Science 59 (4): 176-184
44. RÖTZER T, Chmielewski FM 2001 Phenological maps of Europe. Clim Res 18 (3): 249-257. DOI: http://dx.doi. org/10.3354/cr018249

45. TEGEL W, SEIM A, HAKELBERG D, HOFFMANN S, PANEV M, WESTPHAL T, BUNTGEN U 2013 A recent growth increase of European beech (Fagus sylvatica L.) at its Mediterranean distribution limit contradicts drought stress. Eur J Forest Res 133 (1): 61-71. DOI http://dx.doi. org/10.1007/s10342-013-0737-7

46. DITTMAR C, ZECH W, ELLING W 2003 Growth variations of Common beech (Fagus sylvatica L.) under different climatic and environmental conditions in Europe - a dendroecological study. For Ecol Manag 173 (1-3): 63-78. DOI: http://dx.doi.org/10.1016/S0378-1127(01)00816-7

47. DITTMAR C, ELLING W 2007 Dendroecological investigation of the vitality of Common Beech (Fagus sylvatica L.) in mixed mountain forests of the Northern Alps (South Bavaria). Dendrochronologia 25 (1): 37-56. DOI: http://dx.doi.org/10.1016/j.dendro.2007.01.003

48. VAN DER MAATEN E 2012 Climate sensitivity of radial growth in European beech (Fagus sylvatica L.) at different aspects in southwestern Germany. Trees 26 (3): 777-788. DOI: http://dx.doi.org/10.1007/s00468-011-0645-8

49. MASELLI F, CHERUBINI P, CHIESI M, AMPARO GILABERT M, LOMBARDI F, MORENO A, TEOBALDELLI $M$, TOGNETTI R 2014 Start of the dry season as a main determinant of inter-annual Mediterranean forest production variations. Agr For Meteorol 194: 197-206. DOI: http://dx.doi.org/10.1016/i.agrformet.2014.04.006

50. DOUNAVI A, NETZER F, ČELEPIROVIĆ N, IVANKOVIĆ M, BURGER J, FIGUEROA AG, SCHÖN S, SIMON J, CREMER E, FUSSI B, KONNERT $M$, RENNENBERG $H$ 2016 Genetic and physiological differences of European beech provenances ( $F$. sylvatica L.) exposed to drought stress. For Ecol Manag 361: 226-236. DOI: http://dx.doi. org/10.1016/i.foreco.2015.11.014 
